\title{
Separation Strategies for Processing of Dilute Liquid Streams
}

\author{
Sujata Mandal ${ }^{1}$ and Bhaskar D. Kulkarni ${ }^{2}$ \\ ${ }^{1}$ Expertise Center for Eco-Testing Laboratory, Central Leather Research Institute, Adyar, Tamilnadu, Chennai 600020, India \\ ${ }^{2}$ Chemical Engineering and Process Development Division, National Chemical Laboratory, Dr. Homi Bhabha Road, Maharashtra, \\ Pune 411008, India \\ Correspondence should be addressed to Sujata Mandal, sujata@clri.res.in
}

Received 17 June 2011; Revised 9 September 2011; Accepted 5 October 2011

Academic Editor: Adrian Schumpe

Copyright ( $) 2011$ S. Mandal and B. D. Kulkarni. This is an open access article distributed under the Creative Commons Attribution License, which permits unrestricted use, distribution, and reproduction in any medium, provided the original work is properly cited.

\begin{abstract}
Processing of dilute liquid streams in the industries like food, agro-, biotechnology, pharmaceuticals, environment, and so forth needs special strategy for the separation and purification of the desired product and for environment friendly disposal of the waste stream. The separation strategy adopted to achieve the goal is extremely important from economic as well as from environmental point of view. In the present paper we have reviewed the various aspects of some selected universal separation strategies such as adsorption, membrane separation, electrophoresis, chromatographic separation, and electroosmosis that are exercised for processing of dilute liquid streams.
\end{abstract}

\section{Introduction}

Processing of dilute liquid streams occurs in number of unit processes and unit operations in chemical industries. Whereas the separation strategies adopted by these industries sometimes follow the conventional processes such as distillation, crystallization, drying, and so forth, due to the familiarity of operation since several decades. In industry, handling of dilute liquid streams needs special strategies for the separation and purification of the desired product and for environmental friendly disposal of the waste stream. The separation strategy adopted is extremely important from economic as well as from environmental point of view. The suitability of a separation technique depends on number of factors that includes:

(i) improved selectivity,

(ii) improved energy efficiency,

(iii) development of new process configurations and integration,

(iv) economic viability,

(v) environmental safety and compatibility, and

(vi) sustainability (recycle and reuse).
Numerous new/modified techniques have been exercised by engineers and scientists to improve the efficiency and reduce the cost of the traditional separation techniques. Separation processes of commercial interests can be categorized according to the phases involved as

(i) solid-solid separation (screening, classification, floatation, flocculation, and field-based),

(ii) solid-liquid separation (thickening, centrifugation, filtration, drying, and crystallization),

(iii) solid-gas separation (cyclone, filters, adsorption, etc.),

(iv) liquid-liquid separation (distillation, extraction, membranes, and adsorption),

(v) liquid-gas separation (absorption, stripping, and pervaporation),

(vi) gas-gas separation (membranes), and

(vii) solid-liquid-gas separation.

Each of these categories has several alternative ways to bring about separation. However, it is not possible to look at all such possible strategies exhaustively within a single frame. In the present paper, we wish to look into 
the various aspects of the different universal separation strategies used for processing of dilute liquid streams, such as, adsorption, membrane separation, electrophoresis, chromatographic separation, and electroosmosis.

\section{Separation Methodologies}

2.1. Adsorption. Adsorption is a thermodynamically spontaneous surface phenomenon. When a multicomponent liquid mixture is contacted with a solid surface (adsorbent), certain component of the mixture (adsorbate) gets concentrated at the surface of the solid due to difference in the intermolecular forces of attraction between the components of the liquid mixture and the solid. This formation of adsorbed phase on the surface of the solid adsorbent having a composition different from that of the bulk liquid phase forms the basis of separation by adsorption technology. The process of adsorption is an exothermic phenomenon while it's reverse, that is, desorption, is an endothermic phenomenon. Both adsorption and desorption forms equally essential steps in a practical adsorption process where the adsorbent is repeatedly used for carrying out the separation.

Adsorption technology is considered as an option for separation when high degree of purity is required. Adsorptive separation could provide an alternative to

(i) systems for energy intensive cryogenic distillation and liquefaction,

(ii) conventional distillation systems,

(iii) systems require minimum use of inprocess air and water, and

(iv) complex separation involving high boiling or thermally unstable compounds.

Development of adsorption technology primarily depends on the development and utilization of wide variety of micro- and mesoporous adsorbents with varying pore structure and surface properties, which are responsible for the selective adsorption of specific component from liquid mixtures. The usefulness of an adsorbent in a separation and purification process is a function of its composition, its pore structure and surface properties, the presence and type of functional groups at the surface, its degree of polarity, and its hydrophilic/hydrophobic characteristic. The adsorbent should not be vulnerable to fouling or degradation by the components of the feed stream. The commonly used adsorbents include aluminosilicates (zeolites and molecular sieves), activated carbon, natural and synthetic clays, activated and impregnated aluminas, silica gels, ion-exchange resins, and biopolymeric adsorbents. Each of these groups of adsorbents contains number of subgroups of materials. Development of new adsorbent materials and physicochemical modifications of the existing adsorbents is being continuously studied by the researchers.

The adsorption efficiency of a specific adsorbentadsorbate system depends on a number of factors:

(i) the physicochemical nature of the adsorbentchemical composition, surface properties, and pore structure, (ii) the nature of the adsorbate such as its $\mathrm{pKa}$, functional groups present, polarity, molecular weight, and size, and

(iii) the solution conditions such as solution $\mathrm{pH}$, ionic strength, and the adsorbate concentration.

2.1.1. Modes of Operation of Adsorption Process. The adsorptive separation process can be performed through various modes.

Batch Adsorption Process. The batch process is the intuitive way of studying the efficiency of an adsorbent for adsorptive separation of a specific molecule or ion. Here, a fixed amount of the adsorbent is contacted with a fixed volume of the adsorbate solution of known concentration at constant temperature. The change in concentration of the adsorbate after a fixed time interval gives the adsorption capacity of the adsorbent for the selected adsorbate. This is the first step to design an adsorptive separation process.

Continuous Flow Adsorption Process. In this process, the feed stream is percolated through a fixed-bed column packed with the adsorbent in a continuous flow mode. On near saturation of the adsorbent, as evidenced by breakthrough of adsorbate, the column is removed and regenerated. There are two basic modes for operation of bed or column type adsorbers relating to exhaustion and regeneration of adsorbents, namely, fixed beds and pulsed beds. For high concentration systems typical of certain industrial wastes, pulsed-bed systems are often effective and efficient. In continuous flow process, the reactor can be designed to operate in either upflow or downflow direction. A fixed-bed adsorber can be operated in the upflow mode to minimize pressure drop, channeling and fouling of the adsorbent. In addition, upflow design and operation allows smaller particle sizes of adsorbent to be employed to increase adsorption rate and hence decrease adsorber size.

Adsorption Chromatography. In this process, the feed stream is introduced as a pulse in a purge stream, similar to liquid phase chromatography. This method has been applied for small-scale production of fine chemicals. There are limitations in large-scale separation by adsorption chromatography.

\subsubsection{Applications of Adsorption in Separation and Purifica-} tion. The field of adsorption technology has grown extensively over the past years, and it will continue to grow in the prospective future because of its vast applicability. The endless choice of adsorbent materials and their use in the design of innovative separation processes provide bright future for this technology as a separation tool. Adsorption technology has found numerous applications for separation and purification of dilute liquid mixtures and for product recovery in the chemical, petrochemical, and biochemical industries, in biotechnology and biomedical applications and for water treatment (ground/surface water and effluent). 
The technology has been used for olefin-paraffin separation, fructose and glucose separation, isomer separation (xylene, cresol, and cymene), for breaking azeotropes, recovery of antibiotics, removal of microorganisms, purification and recovery of biomolecules (proteins, vitamins, and enzymes), trace impurity removal, for municipal and industrial waste treatment, ground and surface water treatment, to name but a few. Development of new adsorbents and advanced adsorption methods specialized in compositions, structures, functions, and characteristics made this technology suitable to meet the industrial needs of modern era.

An overview of the separation and purification of different valuable products from dilute solutions and removal of various contaminants from dilute process streams by adsorption technique has been presented.

Industrial Applications. For large-scale industrial separation from dilute liquid streams, adsorption technique has been found to be more sustainable alternative in terms of low energy costs and process economics. One component can selectively be adsorbed in a bed of adsorbent particles, while the other passes through. The adsorbed component can be recovered afterwards by thermal swing adsorption (TSA) or pressure swing adsorption (PSA) depending on the nature of the adsorbent and adsorbate. In this way, the separation can be achieved at ambient temperature. Due to size-selective adsorption characteristics, different forms of zeolite and molecular sieves have gained considerable interest towards their industrial applications [1] for the separation of light olefin/paraffin mixtures [2], glucose-fructose mixtures [3], isomer separation $[4,5]$, breaking azeotropes [6], separation of aromatics for the purpose of purification of chemicals [7], and so forth. In addition to various forms of zeolite, polymeric adsorbents and advanced materials containing metal-organic framework (MOF) have been developed for adsorptive separation of aliphatic and aromatic isomers [8].

Continuous separations of olefin/paraffin mixtures are of high demand in chemical industries. Herden and his coresearchers have extensively studied the separation of olefin/paraffin mixtures using different modified forms of $\mathrm{X}$ - and Y-type zeolites [2, 9, 10]. The studies revealed that $\mathrm{X}$-zeolites ( $\mathrm{Si} / \mathrm{Al}$ ratio 1.3 ) are more appropriate for olefin/paraffin separation. Recent development in this area has shown that adsorbents containing transition metal salts dispersed on high surface area substrates like zeolites, alumina, ion-exchange resins, silica, clays, and activated carbon are more efficient for enhanced separation of olefin/paraffin mixtures in bulk [11-13]. This type of adsorbent comprising of transition metal salts supported on high surface area substrates (zeolite, activated alumina, and silica) are also found useful for desulfurization of commercial diesel fuel $[14,15]$ and adsorptive removal of aromatics [16] in industries.

Biotechnology and Biomedical Applications. Separation and purification of biomolecules like, proteins, vitamins, enzymes, and antibiotics from their dilute solutions is an important task in bimedical and biotechnological applica- tions. In this field of application, the primary focus is given on selectivity of the adsorbent for the specific molecule as well as easy recovery of the molecule from the adsorbent. Studies reporting the use of a wide variety of adsorbents including inorganic mesoporous silica, aluminosilicates, carbon nanotubes, natural and synthetic polymeric adsorbents, polymeric resins, and so forth are reviewed. Different modes of the adsorption process like batch process and continuous flow process are opted to achieve the separation and purification of the desired product.

Being a low-energy consuming and high-yield process, adsorptive separation and recovery of biomolecules, namely, antibiotics and vitamins, from fermentation broth are of great industrial importance. Adsorbents such as nonionic polymeric resins [17], ion-exchange resins [18, 19], activated carbon, molecular sieves, and so forth have been reported to be effective for isolation and recovery of these biomolecules. Separation of $\beta$-lectum antibiotics, such as amoxicillin, ampicillin, cephalexin and cefadroxil, trimethoprim, from bioreactors are achieved by adsorption on polymeric resins, activated carbon and biopolymeric adsorbents [20,21].

DNA separation by adsorption on pure/modified silica and its composites is an important method used in novel technologies that uses microchannels [22]. The principle behind this type of separation relies on DNA molecules binding to silica surfaces in the presence of certain salts and under certain $\mathrm{pH}$ conditions [23]. The other adsorbents used for separation of DNA molecules by adsorption are natural/modified clays [24], aluminosilicates, oxidic minerals like goethite [24] and magnetic nanoparticles, and carbon nanotubes [25].

Separation and purification of proteins is usually carried out by adsorption onto different adsorbents materials packed in a chromatographic column. Adsorbents such as polymeric/composite ion exchangers [26], magnetic nanoparticles [27], cryogel [28], polypyrrole-based adsorbents [29], and mesoporous SBA-15 [30] have been developed and used for separation of proteins. Inorganic and organic-polymeric membranes are also studied by researchers for adsorptive separation of protein molecules [31, 32]. A new concept for the purification of protein in micellar aqueous twophase system using magnetic adsorbent has been reported by Becker et al. [33].

Water Treatment. Adsorption technology is extensively exploited by several researchers for water treatment and its purification [34]. Though a wide variety of adsorbents have been studied for water treatment by adsorption, in practice, a few of them have been practically utilized for the purpose. Adsorbent cost is the key point while selecting the adsorbent for this specific application. The selection of adsorbent is done primarily on the basis of the quality of the required water (drinking/industry/environmentally safe wastewater) and the adsorbent cost. Activated carbon (AcC) obtained from different sources [35, 36], activated and impregnated alumina [37, 38], natural-modified clays [39] and minerals [40, 41], synthetic clays [42, 43], synthetic and modified zeolites [44, 45], polymers, and ion-exchange 
resins $[46,47]$ are among the most exploited adsorbents for water treatment. Being low cost and capacity to adsorb both organic and inorganic contaminants, activated carbon adsorbents and their chemically modified forms are brilliant for ground/surface water as well as wastewater treatment [48, 49]. Activated carbon ( $\mathrm{AcC}$ ) is usually available in four different forms, powder (PAC), granular (GAC), fibrous (ACF), and clothe (ACC). All these four forms of activated carbon obtained from various sources have been investigated for drinking water as well as wastewater purification. Adsorption capacities of activated carbon for various contaminants in aqueous medium (as reported in literature) have been listed in Table 1.

An extensive survey of literature on the removal of inorganic contaminants from water reveals that activated carbon adsorbents are not very effective in removing inorganic contaminates including heavy metals from water/wastewater. In this context, a large number of low-cost materials that include agricultural wastes, natural bio-polymers (chitosan, alginic acid, and cellulose), industrial wastes/biproducts, natural clays, soils and minerals, and their chemically modified forms are studied by several researchers and found to show excellent adsorption property for heavy metal removal as well as for the removal of colorants/dyes from water/wastewater [65-68]. Natural soils have been successfully used by researchers for the removal of inorganic contaminants like, fluoride [69], arsenic [70, 71], iodate [72], phosphates [73], and so forth from surface/ground water. Unfortunately, very little information is available in the literature regarding the recovery of pollutants from these low-cost adsorbent materials, the regeneration of spent sorbents, and the stability and reproducibility of the sorbents. Hence, further research is required for real-life applicability of these low-cost adsorbents.

In addition to the traditional adsorbents, researches are going on for the development of new effective adsorbents that can be regenerated and reused for cost-effective separation process. Many advanced adsorbent materials such as carbon-natural zeolite composite [74], aluminiumloaded shirasu zeolite [75], carbon nanotubes [76], aluminasupported carbon nanotubes [77], zeolite-portland cement mixture [78], zeolite-vermiculite composite [79], cellulosesupported synthetic clay [80], carbon-fly ash composite, thiol-functionalized silica coated activated alumina [81], Ce-Ti oxide [82], and so forth with improved adsorption characteristics are being developed and tested for application in water treatment.

Over the last decade, large progress has been made toward the process development of this technology, but, unfortunately, the development in the field of adsorbent materials is not significant. Successful implementation of the technology for separation of industrial processed streams requires reasonably good understanding of the fundamentals of adsorption and adsorption processes, that is, forces responsible for adsorption, adsorption equilibrium, its temperature dependence, heat of adsorption, process cost, and so forth. The technical challenges involved for further growth in this area is the cost-effective quality separation, which require more efficient way to regenerate and reuse adsorbents, to improve our understanding in tailoring adsorbents for complex system and to improve predictive models for mass transfer, adsorption, equilibrium, and other physical data.

2.2. Membrane Separation. During the past decades, membrane separation processes have been developed and optimized for large-scale industrial applications for separation and purification of desired products present in dilute solutions. In this separation technique, the liquid stream is passed through the membrane module when the solvent molecules pass through the membrane leaving desired product/molecule on the other side. This technology is generally used in bulk rather than precise separation.

The most significant advantage of membrane-based separation systems over other existing separation processes is the consumption of less energy. In addition to energy saving, membrane systems are compact and modular, which facilitate the system an easy retrofit to existing industrial processes. The technology is extensively used in food and beverage industry $[83,84]$, pharmaceutical industries, biotechnology $[85,86]$, in environmental, in the treatment of effluent and process streams [87], and in energy applications. The applications of different membrane-based separation processes used in various industries are discussed as follows.

\subsubsection{Microfiltration and Ultrafiltration (MF and UF). This} is a process for separating materials of colloidal size and larger from true solutions using polymeric membranes. It is used for purification of aqueous streams, concentration, purification, and recovery of valuable products. This is the most widely used among all other membrane processes.

Microfiltration/ultrafiltration (MF/UF) technique is mostly used for aqueous fluid treatments. The application mechanism comprises of purification by the rejection of impurities (e.g., purification of water), by retention and concentration of valuables (purification of biomolecules), and by permeation and purification of valuables (purification of fermentation fluid).

The two most important characteristics for a successful MF/UF process are pore size and economic efficiency of the membrane. For industrial application, the pore size of the membrane must be appropriate for the purpose of separation, and the economic efficiency must be sufficient to allow for the variations in pore sizes needed.

The MF/UF process has been largely used in water treatment for treating natural water, drinking water [88, 89], wastewater, reservoir water [90], and oily water [91]. The technique is also exploited for the treatment of algae-rich water [92], the removal of virus from water and wastewater [93], the removal of colloids and natural organic matter from surface water, and so forth. Several efficient watertreatment technologies that include MF/UF process along with other processes like precipitation/coagulation [94], electroperoxidation [95], ozonation [96], photooxidation [97], and so forth have also been developed. The MF/UF process is also a widely used method for pretreatment of water before reverse osmosis or nanofiltration. Tsai et al. [98] have reported electromicrofiltration method for the removal 
TABLE 1: Adsorption characteristics of activated carbon derived from different sources, reported in the literature, for the removal of various contaminants from water at $25-30^{\circ} \mathrm{C}$.

\begin{tabular}{|c|c|c|c|c|c|c|c|}
\hline $\begin{array}{l}\text { Carbon type } \\
\text { and source }\end{array}$ & Activation & S.A. ${ }^{1}\left(\mathrm{~m}^{2} / \mathrm{g}\right)$ & Adsorbate & $\begin{array}{l}\text { Initial conc. } \\
(\mathrm{mg} / \mathrm{L})\end{array}$ & $\begin{array}{l}\text { Ads. capacity } \\
(\mathrm{mg} / \mathrm{g})\end{array}$ & Model used & Ref. \\
\hline GAC-coal & Untreated & 689 & Aniline & $250-3000$ & 242.92 & Langmuir & {$[50]$} \\
\hline GAC-coal & Untreated & 689 & Pyridine & $250-3000$ & 157.01 & Langmuir & {$[50]$} \\
\hline GAC-coal & Untreated & 689 & Phenol & $250-3000$ & 218.97 & Langmuir & {$[50]$} \\
\hline GAC-coal & Untreated & 689 & Benzene & $250-3000$ & 271.51 & Langmuir & {$[50]$} \\
\hline AcC-waste tire & $\begin{array}{l}\mathrm{HF} \text {, heating at } \\
850^{\circ} \mathrm{C}, \\
\text { chlorination }\end{array}$ & 1060 & Toluene ${ }^{a}$ & 500 & 421.8 & - & {$[51]$} \\
\hline AcC-pine bark & $\begin{array}{c}\text { Heating at } 672^{\circ} \mathrm{C} \\
\text { under } \mathrm{N}_{2} \text { flow }\end{array}$ & 332 & Phenol & 99.75 & $28.20-40.42$ & Langmuir & {$[52]$} \\
\hline ACC & $\begin{array}{c}\text { Conductivity water } \\
\text { at } 60^{\circ} \mathrm{C} \text { under } \mathrm{N}_{2} \\
\text { flow }\end{array}$ & 2500 & $\begin{array}{l}\text { Pesticide } \\
\text { (ametryn) }\end{array}$ & 103.84 & 354.61 & Langmuir & {$[53]$} \\
\hline ACC & -Do- & 2500 & $\begin{array}{l}\text { Pesticide } \\
\text { (aldicarb) }\end{array}$ & 103.96 & 421.58 & Langmuir & [53] \\
\hline ACC & -Do- & 2500 & $\begin{array}{l}\text { Pesticide } \\
\text { (dinoseb) }\end{array}$ & 22.38 & 301.84 & Langmuir & [53] \\
\hline ACC & -Do- & 2500 & $\begin{array}{l}\text { Pesticide } \\
\text { (diuron) }\end{array}$ & 32.27 & 213.06 & Langmuir & {$[53]$} \\
\hline ACC & -Do- & 2500 & $\begin{array}{l}\text { Pesticide } \\
\text { (bentazon) }\end{array}$ & 20.90 & 151 & Langmuir & {$[54]$} \\
\hline ACC & -Do- & 2500 & $\begin{array}{l}\text { Pesticide } \\
\text { (propanil) }\end{array}$ & 23.52 & 114 & Langmuir & {$[54]$} \\
\hline $\begin{array}{l}\text { PAC-Bokbunja } \\
\text { waste seeds }\end{array}$ & Untreated & & $\begin{array}{c}\text { Dye-procion red } \\
\text { MX-5B }\end{array}$ & $10-60$ & 29.37 & Langmuir & {$[55]$} \\
\hline $\begin{array}{l}\text { PAC-Bokbunja } \\
\text { waste seeds }\end{array}$ & $n$-hexane & & -Do- & $10-60$ & 30.65 & Langmuir & {$[55]$} \\
\hline $\begin{array}{l}\text { AcC-sunflower } \\
\text { seed hulls }\end{array}$ & $\mathrm{H}_{2} \mathrm{SO}_{4}$ & 135.2 & $\begin{array}{c}\text { Dye-acid blue } \\
15\end{array}$ & - & 125 & Langmuir & {$[56]$} \\
\hline $\begin{array}{l}\text { AcC-pine-fruit } \\
\text { shell }\end{array}$ & $\mathrm{K}_{2} \mathrm{CO}_{3}$ & 1035 & $\begin{array}{l}\text { Brilliant green } \\
\text { dye }\end{array}$ & 600 & 216.1 & Langmuir & {$[57]$} \\
\hline $\begin{array}{l}\text { AcC-pine-fruit } \\
\text { shell }\end{array}$ & Heating at $600^{\circ} \mathrm{C}$ & 1425 & -Do- & 600 & 284.3 & Langmuir & {$[57]$} \\
\hline $\begin{array}{l}\text { AcC-water } \\
\text { hyacinth }\end{array}$ & $\begin{array}{c}\mathrm{H}_{2} \mathrm{SO}_{4} \text { followed by } \\
\text { heating at } 300^{\circ} \mathrm{C}\end{array}$ & - & Fluoride & $2-25$ & 6.06 & - & {$[58]$} \\
\hline $\begin{array}{l}\text { AcC-water } \\
\text { hyacinth }\end{array}$ & $\begin{array}{c}\mathrm{H}_{2} \mathrm{SO}_{4} \text { followed by } \\
\text { heating at } 600^{\circ} \mathrm{C}\end{array}$ & - & -Do- & $2-25$ & 4.66 & - & {$[58]$} \\
\hline $\begin{array}{l}\text { AcC- } \\
\text { commercial } \\
\text { (coconut) }\end{array}$ & Untreated & 1050 & $\mathrm{NH}_{3}$ & 340.1 & 5.26 & - & {$[59]$} \\
\hline AcC composite & $\begin{array}{l}\text { Sodium alginate }+ \\
\text { chitosan }+ \\
\text { activated carbon }\end{array}$ & - & $\mathrm{Hg}^{2+}$ & - & 576 & - & {$[60]$} \\
\hline $\begin{array}{l}\text { AcC-coconut } \\
\text { shell }\end{array}$ & Untreated & 1280 & $\mathrm{Cr}(\mathrm{VI})$ & 120 & 107.1 & - & {$[61]$} \\
\hline AcC wood & Untreated & 1700 & $\mathrm{Cr}(\mathrm{VI})$ & 120 & 87.6 & - & {$[61]$} \\
\hline AcC coal & Untreated & 1120 & $\mathrm{Cr}(\mathrm{VI})$ & 120 & 101.9 & - & [61] \\
\hline GAC & Water wash & 648 & $\mathrm{Cu}(\mathrm{II})$ & - & 6.14 & Langmuir & [62] \\
\hline GAC & Citric acid & 431 & $\mathrm{Cu}(\mathrm{II})$ & - & 14.92 & Langmuir & {$[62]$} \\
\hline GAC & $\begin{array}{c}\text { Citric acid } \\
\text { followed by } \mathrm{NaOH}\end{array}$ & 448 & $\mathrm{Cu}(\mathrm{II})$ & - & 11.85 & Langmuir & {$[62]$} \\
\hline
\end{tabular}


TABle 1: Continued.

\begin{tabular}{lccccccc}
\hline $\begin{array}{l}\text { Carbon type } \\
\text { and source }\end{array}$ & Activation & S.A. $^{1}\left(\mathrm{~m}^{2} / \mathrm{g}\right)$ & Adsorbate & $\begin{array}{c}\text { Initial conc. } \\
(\mathrm{mg} / \mathrm{L})\end{array}$ & $\begin{array}{c}\text { Ads. capacity } \\
(\mathrm{mg} / \mathrm{g})\end{array}$ & Model used & Ref. \\
\hline $\begin{array}{l}\text { AcC-rubber leaf } \\
\text { AcC-saw dust }\end{array}$ & $\mathrm{HCl}$ & 0.57 & $\mathrm{Cu}(\mathrm{II})$ & $5-50$ & 8.39 & Langmuir & {$[63]$} \\
\hline
\end{tabular}

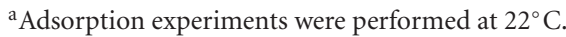

${ }^{1}$ Surface area.

of natural organic matter and inorganic particles from natural surface water. In this method, the microfiltration is performed under an applied electric field when an enhanced removal of natural organic matter and inorganic particulates was obtained because of electrophoretic and electroosmotic effects.

In food processing industry, MF/UF separation technique is used for processing dairy products $[99,100]$, honey [101], fruit/vegetable juice [102, 103], clarification of wine, and decolourization of sugarcane solution [104].

This MF/UF technique is also used for recovery of biomolecules like proteins, enzymes, vitamins, and carbohydrates from milk products [105], vegetable oils [106], fishery products [107], poultry processing wastewater [108], fermentation products [109], and peels of citrus fruits [110].

However, the main problem of MF/UF process is the flux decrease caused by concentration polarization and membrane fouling. Several processes have been tried by researchers for preventing/reducing the membrane fouling.

2.2.2. Reverse Osmosis (RO). This is a liquid/liquid separation process that uses a dense semipermeable membrane, highly permeable to water and highly impermeable to microorganisms, colloids, dissolved salts, and organics. This is the first membrane-based separation process to be widely commercialized. This technique is largely used for water treatment $[111,112]$, namely, production of demineralized or potable drinking water, desalination of seawater and brackish water, and pure boiler water makeup in industrial fields, and in food processing industries, and wastewater treatment and reuse.

The largest single application area of reverse osmosis is desalination of seawater and brackish waters $[113,114]$. Cellulose acetate membranes and thin-film composite membranes made from aromatic polyamides $[115,116]$ are widely used for this purpose. Several pretreatment methodologies like flocculation/precipitation, MF/UF [117], nanofiltration [118], adsorption, electrocoagulation [119], and so forth for seawater reverse osmosis are tried to increase the membrane life by reducing membrane fouling. RO separation of seawater and brackish water containing high total dissolved solid (TDS) is considered to be less energy consuming than electrodialysis. It is also used for the removal of boron from water [120].

In addition to the desalination of water, $\mathrm{RO}$ technique is also being used for the production of drinking water, water treatment for boilers, feed water treatment for industrial use, the removal of organic and inorganic contaminants from water, wastewater treatment and reuse [121-124].
Other applications of reverse osmosis separation technique include purification of lactic acid from fermentation broth [125], separation of organic/inorganic compounds from their aqueous solutions [126, 127], separation of organics from multicomponent mixtures [128], boric acid recovery [129], and so forth.

2.2.3. Electrodialysis (ED). This is an electrochemical separation process in which ionic species are separated from an aqueous solution or from other uncharged components using electrically charged membranes under the driving force of electrical potential difference. Though the separation technique was first developed for the desalination of brackish water as can be seen from the recent works of Sadrzadeh and Mohammadi $[130,131]$ and many other research groups but at present, the most important industrial application of electrodialysis is in the production of potable water. This technique is widely used for the removal of dissolved metal ions and solids from industrial processed/waste streams and concentration of metal ions from their solutions [132, 133]. The removal of inorganic contaminants like fluoride $\left(\mathrm{F}^{-}\right)$, nitrate $\left(\mathrm{NO}_{3}{ }^{-}\right)[134]$, and boron $\left[\mathrm{B}(\mathrm{OH})_{4}{ }^{-}\right]$from dilute aqueous streams are also performed by electrodialysis method [135] through different ion-exchange membranes [136]. It can also be utilized for separation and concentration of salts [137], acids (mineral and organic) [138-140] and bases from aqueous solutions, separation of monovalent ions from multiple charged components [141], and separation of ionic compounds from uncharged molecules [142]. Due to the diversity and practicability of the technique, it can be a versatile tool to meet specific needs from chemical [143], biochemical [144], biotechnological [145], food [146], and pharmaceutical industries [147, 148]. Electrodialysis-based separation techniques have been reviewed by $\mathrm{Xu}$ and Huang [149]. In recent days, slightly modified form of electrodialysis with ultrafiltration membrane has been developed to separate valuable biolmolecules [150] on the basis of their electrical charge and size or molecular weight. In this process, a conventional electrodialysis cell is used, in which some ion exchange membranes are replaced with ultrafiltration membranes [151], compounds of higher molecular weight than the membrane cutoff can be separated so as to extend the field of application of electrodialysis to biological charged molecules.

2.2.4. Pervaporation. Pervaporation is a membrane-based separation technique used for separation and concentration of liquid mixtures, especially of aqueous-organic azeotropes [152]. In this technique, the liquid mixture to be separated 
get contacted on one side of the membrane, and the permeate is removed as a vapor from the other side. The membrane acts as a selective barrier between the two phases, the liquid feed solution and the vapor phase permeate. Transport through the membrane is induced by the difference in partial pressure of the components on the two sides (the feed solution and the permeate vapor phase) of the membrane. The mass transport across the membranes involves three successive steps.

(i) Upstream partitioning of the feed components between the flowing liquid feed and the upstream surface layer of the membrane.

(ii) Diffusion of the components through the membrane.

(iii) Desorption of the components at the permeate side of the membranes.

The steady-state mass transport system depends on the parameters, like, upstream pressure, downstream pressure, temperature, and film thickness. When the downstream pressure is low, the flux is inversely proportional to the film thickness. Though the first industrial application of pervaporation was for the dehydration of alcohol/water azeotropic mixtures, presently the technology finds wide industrials applications for separation of and recovery from various liquid mixtures. For being economical, safe, and ecofriendly process, pervaporation separation is considered to be a promising alternative to conventional energy intensive separation technologies, like extractive or azeotropic distillation in liquid mixtures. Pervaporation can be considered the so-called "clean technology," especially for the separation of volatile organic compounds $[153,154]$. The technology is highly used for the separation of organics like aliphatic and aromatic alcohols, acids, benzene, toluene, tetrahydrofuran, ethylene glycol, and so forth from dilute aqueous solutions $[155,156]$. It is also extensively used for the separation of organic/organic mixtures [157], organic azeotropic mixtures [157-159], and separation of isomers [160, 161]. The technique has been studied for the recovery of natural aroma compounds in food industry [162].

Natural biopolymers like chitosan and sodium alginate have attracted considerable attention during the last decade as membrane material for pervaporation separation [163165]. Due to hydrophilic nature and ability to modify/tune their structures to achieve the desired separation, sodium alginate has fascinated wide group of researchers. Sodium alginate is the widely studied membrane in pervaporation dehydration of industrial solvents like ethanol, isopropanol, acetic acid, tetrahydrofuran, and so forth. The performances of sodium alginate-based membranes are reported to be outstanding in dehydration of organics from aqueousorganic mixtures. Use of sodium alginate membrane and its various modified forms in pervaporation dehydration studies has been increasing over the years. Figure 1 shows the trend of published literature on the use of sodium alginatebased membranes for pervaporation separation of aqueousorganic mixtures for past few years.

Aminabhavi and his research group have extensively studied the application of sodium alginate and its modified

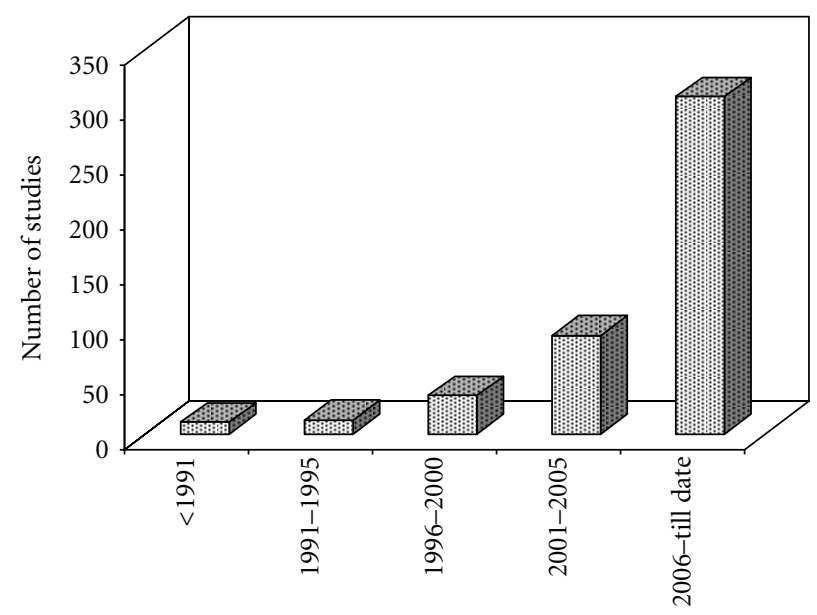

Figure 1: Number of studies reported in literature on the use of sodium alginate-based membranes for pervaporation separation of aqueous-organic mixtures (sources used: ScienceDirect online search, online ACS journals, online library of wiley publication and online journals of Taylor and Francis Publication).

membranes in pervaporation separation of aqueous-organic mixtures. Different types of blend, grafted, and mixed matrix sodium alginate membranes are prepared and tested for their pervaporation performances by the research group of Aminabhavi. A comparison in the pervaporation performance of sodium alginate-based membranes with that of other polymeric membranes for the separation of waterisopropanol mixture at $30^{\circ} \mathrm{C}$ has been listed in Table 2 . The data presented are based on the reported works by Aminabhavi and his research group.

Table 2 shows that even though isopropanol separation has yielded poor selectivity with pure sodium alginate membrane, but large improvements were observed by incorporating sodium alginate with fillers like MCM-41, SBA15, $\mathrm{Na}^{+} \mathrm{MMT}, \mathrm{AlPO}_{4}-5$, and so forth. However, the use of sodium alginate membrane for separation of organic-organic mixture by pervaporation is rare.

Although pervaporation through polymeric membranes is the most exploited one, several inorganic polymeric composite membranes with higher thermal and mechanical stability have also been developed by the researchers to make the transport process faster in pervaporation [168]. Apart from composite membranes, inorganic (zeolites and silicabased ceramic) membranes [169] also have been attracting attention of researchers in the recent years because of their tailored selectivity, high flux and low energy consumption in addition to provide a scope for combined reactionseparation systems.

Different hybrid pervaporation techniques such as pervaporation adsorption [170], distillation pervaporation [171], and so forth are also practiced for improved separation and enhanced recovery.

Simultaneous reaction separation by combination of pervaporation with chemical reactors has become an interesting alternative to the conventional process. In a pervaporation reactor, separation of product from the reaction system 
TABle 2: Pervaporation performance of different types of membranes for the separation of water-isopropanol mixture with $10 \mathrm{wt}$. $\%$ feed water at $30^{\circ} \mathrm{C}$.

\begin{tabular}{|c|c|c|}
\hline Membrane type & Selectivity & Ref. \\
\hline PVA & 77 & {$[166]$} \\
\hline $\begin{array}{l}\text { PVA/PMMA blend } \\
\text { membrane ( } 5 \% \text { PMMA) }\end{array}$ & 400 & [166] \\
\hline $\begin{array}{l}\text { PVA-PMA blend } \\
\text { membrane ( } 4 \% \text { PMA) }\end{array}$ & 2342 & [167] \\
\hline \multicolumn{3}{|l|}{$\begin{array}{l}\text { Pristine/blend/grafted } \\
\text { sodium alginate } \\
\text { membranes }\end{array}$} \\
\hline Sodium alginate (pristine) & 650 & [165] \\
\hline $\begin{array}{l}\text { Poly(acrylamide) grafted } \\
\text { sodium alginate }\end{array}$ & 100 & [165] \\
\hline Sodium alginate/PVA blend & 580 & [165] \\
\hline $\begin{array}{l}\text { Sodium alginate/pAAm } \\
\text { grafted GG blend }\end{array}$ & 890 & [165] \\
\hline $\begin{array}{l}\text { Sodium alginate }+5 \text { wt. } \% \\
\text { PVA }+10 \text { wt. } \% \text { PEG }\end{array}$ & 3600 & [165] \\
\hline \multicolumn{3}{|l|}{$\begin{array}{l}\text { Mixed matrix membranes } \\
\text { of sodium alginate }\end{array}$} \\
\hline $\begin{array}{l}\text { MCM-41 (10 wt.\%) filled } \\
\text { sodium alginate }\end{array}$ & 30,000 & [165] \\
\hline $\begin{array}{l}\text { SBA-15 (10 wt. } \%) \text { filled } \\
\text { sodium alginate }\end{array}$ & $\infty$ & [165] \\
\hline $\begin{array}{l}\text { Fe-SBA-15 }(10 \mathrm{wt} . \%) \text { filled } \\
\text { sodium alginate }\end{array}$ & $\infty$ & [165] \\
\hline $\begin{array}{l}\mathrm{Na}^{+} \mathrm{MMT}(10 \mathrm{wt} . \%) \text { filled } \\
\text { sodium alginate }\end{array}$ & $\infty$ & [165] \\
\hline $\begin{array}{l}\mathrm{AlPO}_{4}-5(20 \mathrm{wt} . \%) \text { filled } \\
\text { sodium alginate }\end{array}$ & 69,000 & [165] \\
\hline $\begin{array}{l}\text { Al-MCM-41 ( } 20 \text { wt. } \%) \\
\text { filled sodium alginate }\end{array}$ & $\infty$ & [165] \\
\hline
\end{tabular}

enhances the conversion and hence the products yield [172]. The removal of product during reaction in a pervaporation reactor suppresses the formation of byproduct. Pervaporation membrane reactor is one such reaction-separation system implemented for esterification reactions [172], production of butanol, extraction of aroma components from fermentation reactors, resin production [173], wastewater treatment, and so forth [174]. A new concept of hybrid pervaporation membrane reactor system described by Park and Tsotsis [175], which integrates pervaporation reactor system with adsorption in the permeate side. Park and Tsotsis have validated the hybrid pervaporation membrane reactor system by performing esterification of acetic acid by ethanol.

The major constraints for practical application of the membrane technology for processing of dilute liquid streams are the need for membrane that can work efficiently in real-world applications in complex matrix of the processed streams and high scaleup costs for large-scale applications.
The current needs for further development of the membrane technology include the following.

(i) Development of low-cost membranes with high surface area per unit volume.

(ii) Development of high temperature membranes (ceramic/metal), nanocomposites, targeted to specific commercial applications.

(iii) Increasing membrane life with antifouling and antiflux schemes.

(iv) Regeneration/low-cost maintenance of the membranes.

(v) Integration of the membrane technology with other separation technologies.

(vi) Improved design and information tools for predicting membrane performance.

(vii) Process scaleup.

2.3. Electrophoresis. Electrophoretic separation may be the major technique for molecular separation in today's cell biology laboratory for analytical as well as for preparative purposes. This is an inexpensive and powerful technique for separation in molecular level. Electrophoretic separation technique is based on the differential migration of electrically charged particles in an electric field. Hence, this technique is applicable only to ionic or ionogenic materials. The mediums used in biochemical applications are usually aqueous solutions, suspensions, or gels.

The key mechanism in the theory of electrophoresis is the electrical double layer, which is formed by the fixed charges of the macromolecules (or colloid) with the relatively mobile counter ions of the surrounding fluid. The thickness of the double layer is normally given by the inverse of the DebyeHuckel constant $\kappa$

$$
\frac{1}{\kappa}=\left(\frac{\varepsilon k T}{8 \pi e^{2} n_{o} z^{2}}\right)^{1 / 2},
$$

where $e$ is the electronic charge, $k$ is the Boltzmann constant, $n_{o}$ is the bulk concentration of each ionic species, $z$ is the valence of the electrolyte, and $\varepsilon$ is the dielectric constant.

The total charge of the electrical double layer is zero; however, the spatial distribution of charges is not random and hence gives rise to the electric potential. The mobile counter ions are bound sufficiently tightly to the macromolecules so that, during electrophoresis, the mobile counter ions moved together with the macromolecules.

Electrophoresis can be one dimensional (i.e., one plane of separation) or two dimensional. One-dimensional electrophoresis is used for most routine protein and nucleic acid separations. Two-dimensional separation of proteins is used for finger printing. Alternatively, the electrophoretic technique may be of the following types: moving boundary electrophoresis (MBE), zone electrophoresis (ZE), disc electrophoresis, isoelectric focusing (IEF), sodium dodecyl sulphate/polyacrylamide gel electrophoresis (SDS/PAGE), isotacophoresis (ITP), DNA sequencing, immobilized $\mathrm{pH}$ 
gradients (IPG), pulsed-field gel electrophoresis, and capillary zone electrophoresis. The latest addition in the list is chromatophoresis, which is direct coupling of HPLC with SDS/PAGE and thus provide a new type of 2-D map. Moving boundary electrophoresis, capillary electrophoresis, and zone electrophoresis are the separation techniques primarily used in analytical methods. While most of the electrophoresis techniques have been used for analytical purposes, zone electrophoresis and isoelectric focusing are the two variations, which are also useful for preparative separations of protein mixtures.

Zone electrophoresis is characterized by the complete separation of charged solutes into separate zones. Many of the earlier separations of this type were carried out using filter paper in a Durum cell. Capillary electrophoretic technique has been used for the separation of DNA, proteins, in biotechnology and cell-biology applications [176, 177]. The technique is also used for chiral separation in pharmaceutical industry [178]. Prior to dramatic improvements in chromatographic techniques, continuous electrophoresis was popular for purifying proteins such as enzymes and amino acids $[179,180]$. Electrophoresis is still invaluable on an analytical scale, but large scale electrophoretic separations were not established because the technique does not translate well to large sizes, mainly because of the difficulties to remove the generated heat during the separation and also because the process is very slow. During the recent decade, lot of progress has been made in electrophoretic separation technique.

2.4. Chromatographic Techniques. Different forms of chromatographic separation techniques are widely used in separation and purification of industrial process streams, such as for purification of groundwater, separation of chiral compounds in pharmaceutical industries, and separation of biomolecules in bio-chemical/biomedical applications. The chromatographic techniques are broadly classified into two categories depending on the physical state of the mobile phase, gas chromatography (GC), and liquid chromatography (LC). As the present paper deals with separation in solution; hence, the discussion is restricted within liquid chromatography.

2.4.1. Liquid Chromatography (LC). This is the chromatographic technique in which the mobile phase is a liquid. Depending on the separation mechanism, the liquid chromatography can be classified into the following subcategories.

High-Performance Liquid Chromatography (HPLC). This is a highly improved form of column chromatography. In this technique, the liquid mobile phase along with the sample to be separated is moved through the stationary phase (packed column) under high pressure with the help of a pump. Materials of much smaller particle size and hence very high surface area can be used for column packing. This allows a much better separation of the components in the mixture. The most common application of HPLC is in analysis [181].
Ion-Exchange Chromatography (IEC). IEC is often applied to the separation of acidic or basic samples, whose charge varies with $\mathrm{pH}$. In this technique, the separation occurs through exchange or interchange of ions between the sample solution and the solid stationary phase. Primarily the ion exchange chromatography is regulated by electrostatic interactions between the ions being exchanged (the mobile ions in the sample) and the fixed ions that are attached covalently to the molecular lattice of the ion-exchanger.

Affinity Chromatography. This technique is largely used for isolation and purification of biological materials like, proteins, enzymes, antibodies, antigens, viruses, and intact cells by their reactivity with specific immobilized substances. This chromatographic technique is based on the principle that the molecule to be purified can form a selective but reversible interaction with another molecular species immobilized on a suitable chromatographic support. When the chromatographic support is a membrane, it is called as affinity membrane chromatography. Microporous/macroporous membranes containing functional ligands attached to their inner pore surface are used as adsorbents. Affinity membrane chromatography is a promising large-scale separation process for the isolation, purification, and recovery of proteins and enzymes [182-184]. Immobilized-metal affinity chromatography is relatively a new and advanced technique appropriate for protein purification [185]. Feng et al. [186] have synthesized a new immobilized-metal affinity chromatography adsorbent with paramagnetism for the separation and purification of protein. Separation through affinity chromatography can be performed by two different techniques, column chromatography and batch methods, of which batch method is usually applied for largescale preparative separations. Affinity chromatography in batch mode is becoming more popular with the growth of biotechnology industry.

Size Exclusion Chromatography (SEC). Separation and retention in SEC are determined by the hydrodynamic diameter of the solute molecule relative to the size of the pores of the column packing. Thus, in SEC, the solutes are eluted according to decreasing molecular size and maximum available volume for separation is equal to the total pore volume of the packing medium. This technique is popular for the purification of protein molecules [187, 188] because of high recovery and its ability to remove undesirable aggregates (dimers, oligomers, etc.) from protein products [189]. Technical improvement of SEC to high-performance SEC (HPSEC) led to more rapid separation and increased resolution [190].

Reversed Phase Chromatography (RPC). This is the most popular liquid chromatographic technique of separation. In this technique, an aqueous/organic solvent mixture is commonly used as the mobile phase and a high surface area nonpolar solid (usually an alkyl-bonded silica packing) is used as the stationary phase. 
Chiral Chromatography. This chromatographic technique is primarily used for separating stereoisomers, that is, chiral compounds.

Thin-Layer Chromatography (TLC). This is a planar chromatography in which the mobile phase moves through the stationary phase of a thin layer of adsorbent like silica gel, alumina, or cellulose, on a flat and inert substrate. The driving force of the solvent system and the retarding action of the stationary phase are responsible for the separation in TLC. Compared to other planar chromatographic techniques, it has the advantage of faster runs, better separations, and the choice of variety of adsorbents. High-performance TLC has also been developed for the better resolution. TLC is a laboratory separation technique that is used for the separation of organic compounds in solution.

The chromatographic separations can be performed in batch as well as in continuous mode [191]. Among all the above chromatographic techniques, different forms of column chromatography in continuous mode (simulated moving-bed chromatography, SMBC) are the most widely used technique for industrial separation. Simulated movingbed chromatography (SMBC) is the most widely used technique as it requires less solvent for product elution and would be less cost intensive than for batch chromatography [191].

The continuous simulated moving bed chromatographic reactors have been extensively studied for many different separation schemes arising in the fine chemical, pharmaceutical, biotechnology, and petrochemical industries. Typical successful examples include $p$-xylene separation from its C8 isomers, $n$-paraffins from branched and cyclic hydrocarbons, olefins from paraffins, sugar-processing industry, chiral and enantiomers of isoflurane, enflurane, dilute binary gases, and other multicomponent systems.

The operation of a simulated moving bed provides a practically convenient way to mimic true moving bed acquiring all its advantages while eliminating the disadvantages arising due to solids motion. Over the years, a number of improvements in SMB operation modes such as in gas phase, supercritical conditions, and so forth have been made for specific applications. A generic design strategy for an SMBC separation system begins with the knowledge of the equilibrium and kinetic parameters with a view to determine the operating parameters, amount of adsorbent, pressure constraints, column geometry, and so forth for obtaining maximum productivity value. The results provide an assessment of whether the process is reasonable. Continuous models accounting for the mass transfer, heat transfer, pressure drop effects, and so forth are solved providing separation region analysis. An optimization procedure is then implemented to improve separation productivity for a given adsorbent/desorbant consumption, feed flow rates, constant columns number, and arrangement. The optimized solution is then detailed and simulated with a discontinuous model.

A typical case study employs the SMBC for the downstream processing of recombinant proteins using a twostep salt gradient in three-zone open loop continuous countercurrent process for the purification of recombinant streptokinase. Possible process parameters and conditions for efficient separation are obtained through simulations. The model-based design of an SMBC unit requires the knowledge of the properties of the adsorbent phase such as its particle size, density, porosity, pore radius, heat capacity, and so forth. Likewise the model needs the data on the fluid phase components equilibrium adsorption parameters over the adsorbent materials such as its maximum loading capacity, adsorption equilibrium constants, and isosteric heat of adsorption of the components. Additionally, knowledge of Henry constants at different temperatures and mass transfer parameters (pore diffusion, axial dispersion, and external mass transfer coefficient) and heat transfer (heat conductivity, component fluid heat capacities, and Biot number) parameters is essential.

Simulated moving-bed chromatography (SMBC) is the most popular method for industrial separation of optical isomers [192-194], where a number of columns are connected in series with inlet/outlet lines connected between the columns. Recently, a multicolumn continuous chromatographic separation method named as "VARICOL" has been developed by Ludemann-Hombourger and his coworkers $[195,196]$ which is based on the principle of asynchronous shift of the inlet/outlet lines in a multicolumn system on a recycle loop. The newly developed method "Varicol" is proposed to be more efficient than the traditional simulated moving-bed technique. Another form of chiral resolution process for the separation of racemic mixture of difluoromethylornithine (DFMO $\mathrm{HCl}$ ) in industrial scale has been proposed by Perrin et al. [197] involving a multicolumn continuous enantioselective chromatographic process coupled with enantioselective crystallization process. The other chromatographic techniques used for chiral separation are high-performance liquid chromatography (HPLC), gas chromatography (GC), supercritical fluid chromatography (SFC), thin-layer chromatography (TLC), and capillary electrochromatography (CEC).

The SMBC technique involving various separation mechanisms (adsorption, ion exchange, and so forth) is also being successfully employed for the separation of $p$-xylene isomers [198] and in the separation of glucose and fructose [199201]. The new challenge for the SMB technology is its application to the separation and purification of biomolecules [202]. Examples of products that are considered for SMBC separation and purification are proteins [203, 204], amino acids [205], antibodies [206], nucleosides [207], and plasmid DNA [208].

$\mathrm{Du}$ et al. [209] have developed a system for lowspeed rotary countercurrent chromatography by utilizing a convoluted multilayer helical tubing to be used for industrial separation. High-performance centrifugal partition chromatography (HPCPC) is also a practical and suitable method for the separation of biomolecules such as proteins, enzymes, and so forth, particularly on the preparative scale [210].

2.5. Electroosmosis. Electroosmosis, also called electroendosmosis, is the motion of polar liquid through a porous 
membrane or any other porous structure under the influence of an applied electric field. If a solution is separated by a porous diaphragm and an e.m.f. is applied between the electrodes placed on each side of the diaphragm, there will be a flow of liquid from one side to the other. The movement of liquid is also known as electroosmotic flow. A porous diaphragm behaves as a mass of small capillaries. Glass capillaries can also be used for the electroosmotic flow to be observed. In each case, the charged layer attached to the solid cannot move and so the diffused layer in the liquid phase together with the liquid moves under the influence of an electric field. The direction of the electroosmotic flow depends on the diffuse part of the double layer. In moderately pure water, most solids acquire a negative charge so that the diffuse layer has a resultant positive charge, and hence, the flow of water is generally towards the cathode.

Electroosmotic separation technique has industrial importance for separation of water from colloidal suspensions as it consumes less energy than the conventional technique like evaporation. The most recent development in this technology has involved enhanced mixing efficiency by introducing a nonuniform zeta potential, and the enhancement in mixing was experimentally observed by Herr et al. [211]. In 1930, Bartow and Jebens [212] reported water purification by Electroosmosis through a diaphragm. The water so purified was claimed to be equivalent to distilled water and could be obtained at a much lower cost. Electroosmotic separation technique was applied along with vacuum separation technique for the separation of iron oxide ultrafines [213]. The cationic surfactant $\mathrm{CTAB}$ was used to maintain the zeta potential in order to achieve the electroosmotic separation of the uncharged ultrafines from iron oxide slurry. A sludge (water treatment process sludge) treatment method by electroosmotic dewatering has been proposed by Buijs et al. [214]. Buijs and coworkers have performed electroosmotic dewatering of commercial sludge on pilot plant scale and on real process scale. The energy consumption for dewatering was found to be within the range of $20-40 \mathrm{~kJ} \mathrm{~kg}^{-1}$. The removal of water from food suspensions is of great interest in food technology. Al-Asheh et al. [215] reported a direct current Electroosmosis dewatering technique to concentrate tomato to the conventional paste suspension. The process was claimed to save $70 \%$ of energy as compared to the evaporation technique. The electroosmotic technique has been used by several researchers for removing water soluble organics from soil for soil remediation purpose [216], dewatering of filter cakes of activated sludge [217], and so forth.

2.6. Hybrid Separation Techniques. In addition to the separation techniques described above, several forms of hybrid separation processes have been developed and applied to achieve the desired separation in dilute liquid streams. These hybrid processes usually involve two or more than two different separation techniques. Sarangi and Pattanaik have developed such a separation process comprising of reverse osmosis $(\mathrm{RO})$ and solvent extraction techniques for recovering copper from dilute solutions [218]. An integrative membrane coagulation-adsorption bioreactor was developed by Tian et al. [219] for the removal of organic matter in drinking water treatment. Many novel separation processes involving electrophoresis and other separation techniques like solvent extraction, chromatography, isoelectric focusing are developed for the separation of ionic biomolecules as well as inorganic ions [180, 220]. Spoor et al. [221] reported pilot scale deionization of galvanic nickel solution using a hybrid ion-exchange/electrodialysis system. Decolourization of reactive dyes from an aqueous solution by combined coagulation/micellar-enhanced ultrafiltration process has been reported by Ahmad and Puasa [222]. Den and Wang [223] suggested a hybrid separation method for treatment of brackish water. The method consists of pretreatment of the brackish water by electrocoagulation (for removing silica) followed by reverse osmosis. According to Den and Wang, pretreatment of brackish water by electrocoagulation prevents the fouling of $\mathrm{RO}$ membrane and hence increases the membrane life. Nataraj et al. have developed hybrid separation techniques by combining nanofiltration (NF) with reverse osmosis (RO), microfiltration (MF) with electrodialysis (ED) and took the techniques upto pilot-scale level for water/wastewater treatment. Nataraj et al. [224] have reported a pilot-scale skid-mounted system comprising of nanofiltration (NF) and reverse osmosis membrane processes for the treatment of distillery wastewater. Commercial NF membrane and thin-film composite (TFC) polyamide RO membrane in spiral wound configuration was used in the process. The same NF-RO process was successfully used for removing dye and salts from simulated water in pilot scale by Nataraj et al. [225]. Pilot plant of a hybrid microfiltration (MF) and electrodialysis (ED) system was also designed, constructed, and employed successfully by Nataraj et al. [226] for the treatment of paper industry wastewater. In this hybrid MF-ED process, Nataraj et al. have used microfiltration module of ceramic membrane as a pretreatment step for the electrodialysis pilot-scale unit operation. The electrodialysis pilot-scale unit designed by them consisted of membrane stack of a series of cation exchange and anion exchange membranes. The hybrid MFED process could recover $80 \%$ of the wastewater.

\section{Discussions and Future Needs}

Developments of separation and purification technology for processing of dilute liquid streams have been reviewed with special focus on adsorption, membrane-based techniques, chromatography, and electrokinetic-based separation techniques (Electroosmosis, electrophoresis).

Because of the vast applicability of adsorption technology, it has grown extensively over the past years, and still new/modified adsorbents are being added into the list. Also in the recent years, a lot of novel adsorption processes have been developed for enhanced separation and purification of the processed streams. Despite the development of a large number of new/modified adsorbents, very few of them are set for their practical application in industrial processed streams. Successful implementation of adsorbent and adsorption necessitates reasonably good understanding 
of the fundamentals of the process. Synthesis of advanced materials with high chemical and thermal stability, cost effectiveness of the process, improved predictive models for mass transfer, adsorption, equilibrium, and other physical data is the challenges for further growth of this technology in future.

The extensive literature on membrane separation indicates that the use of membranes in separation and purification processes is growing steadily, and it is believed that membrane separation can play an important role in reducing the environmental impact largely. A wide range of membrane materials has been investigated by the researchers to achieve enhanced and quality separation. Nevertheless, the major constraint for limited application of this technology is high scaleup costs for large-scale applications. It is required to develop robust functional tailored materials with high mechanical and thermal stability, enhanced permeability and selectivity, and economic process scaleup for extensive and versatile application of the technique and to meet the future needs.

Chromatographic separation in batch mode is considered to be very expensive technique. Nevertheless, the continuous chromatography have shown considerable advantages over the batch mode as it better utilizes the adsorbent materials, reduce solvent consumption, and increase productivity. Simulated moving bed chromatography is the most popular among all existing separation techniques for separation of chiral compounds in pharmaceutical industries and separation of biomolecules in bio-chemical and biomedical applications. Among a vast range of existing materials, only very few can practically serve as the perfect materials for specific separation to be used as stationary phase in industrial applications. Hence, there is a necessity to develop/identify materials suitable for stationary phase and mobile phase. Also there is urgent need to develop flexible, fast scaleup, and economically viable process for enhanced separation.

Notwithstanding the differences in the strategies for separation, the research needs for further improvements in the separation techniques can be covered under the common categories as [227] the following.

(i) Synthesis of new advanced materials (adsorbents, membrane materials, specialty materials, functional polymers, etc.) improves performance.

(ii) Their physicochemical data bases (thermodynamics and kinetics parameters).

(iii) Understanding the role and effects of uncertainties in proposed mechanism (such as nucleation, growth, surface interaction, transport, etc.).

(iv) Understanding the dynamics of exchange processes at the interface.

(v) Lack of direct measurements of variables of interest (e.g., in situ sampling, analytical and flow visualization).

(vi) Development of sensors and other analytical measurement instruments.

(vii) Development of better predictive modeling tools covering length-time scales of interest. (viii) Use of models for product quality control and optimization of process systems.

(ix) Hybridization: combined separation operations or reaction and separation.

(x) Molecular recognition as a basis for separation.

(xi) Fundamental understanding, new equipment, and test facilities.

\section{Acknowledgment}

The authors wish to acknowledge the financial support by Council of Scientific and Industrial Research, India.

\section{References}

[1] C. D. Chudasama, J. Sebastian, and R. V. Jasra, "Pore-size engineering of zeolite A for the size/shape selective molecular separation," Industrial and Engineering Chemistry Research, vol. 44, no. 6, pp. 1780-1786, 2005.

[2] H. Herden, W.-D. Einicke, M. Jusek, U. Messow, and R. Schöllner, "Adsorption studies of $n$-Olefin/ $n$-paraffin mixtures on X-and Y-zeolites. I. Comparison of liquid phase and vapor phase adsorption of hexane- 1 and $n$-hexane on $\mathrm{NaX}$ zeolite," Journal of Colloid And Interface Science, vol. 97, no. 2, pp. 559-564, 1984.

[3] Y. L. Cheng and T. Y. Lee, "Separation of fructose and glucose mixture by zeolite Y," Biotechnology and Bioengineering, vol. 40, no. 4, pp. 498-504, 1992.

[4] A. Methivier, "Influence of oxygenated contaminants on the separation of $\mathrm{C}_{8}$ aromatics by adsorption on faujasite zeolites," Industrial and Engineering Chemistry Research, vol. 37, no. 2, pp. 604-608, 1998.

[5] Z. Guo, S. Zheng, and Z. Zheng, "Separation of pchloronitrobenzene and $o$-chloronitrobenzene by selective adsorption using silicalite-1 zeolite," Chemical Engineering Journal, vol. 155, no. 3, pp. 654-659, 2009.

[6] S. Al-Asheh, F. Banat, and N. Al-Lagtah, "Separation of ethanol-water mixtures using molecular sieves and biobased adsorbents," Chemical Engineering Research and Design, vol. 82, no. 7, pp. 855-864, 2004.

[7] R. B. Eldridge, "Olefin/paraffin separation technology: a review," Industrial and Engineering Chemistry Research, vol. 32, no. 10, pp. 2208-2212, 1993.

[8] M. Maes, L. Alaerts, F. Vermoortele et al., "Separation of C5hydrocarbons on microporous materials: complementary performance of MOFs and zeolites," Journal of the American Chemical Society, vol. 132, no. 7, pp. 2284-2292, 2010.

[9] H. Herden, W. D. Einicke, and R. Schöllner, "Adsorption of $n$-hexane/ $n$-olefin mixtures by $\mathrm{NaX}$ zeolites from liquid solution," Journal of Colloid And Interface Science, vol. 79, no. 1, pp. 280-283, 1981.

[10] H. Herden, W. D. Einicke, U. Messow, K. Quitzsch, and R. Schöllner, "Adsorption studies of $n$-olefin $/ n$-paraffin mixtures on X- and Y-zeolites. II. Adsorption of tetradecene-1/ndodecane mixtures on modified X- and Y-zeolites," Journal of Colloid And Interface Science, vol. 97, no. 2, pp. 565-573, 1984.

[11] R. T. Yang and E. S. Kikkinides, "New sorbents for olefin/ paraffin separations by adsorption via $\pi$-complexation," AIChE Journal, vol. 41, no. 3, pp. 509-517, 1995. 
[12] A. van Miltenburg, W. Zhu, F. Kapteijn, and J. A. Moulijn, "Adsorptive separation of light olefin/paraffin mixtures," Chemical Engineering Research and Design, vol. 84, no. 5A, pp. 350-354, 2006.

[13] J. Padin, R. T. Yang, and C. L. Munson, "New sorbents for olefin/paraffin separations and olefin purification for $\mathrm{C}_{4}$ hydrocarbons," Industrial and Engineering Chemistry Research, vol. 38, no. 10, pp. 3614-3621, 1999.

[14] A. J. Hernández-Maldonado and R. T. Yang, "Desulfurization of commercial liquid fuels by selective adsorption via $\pi$ complexation with $\mathrm{Cu}(\mathrm{I})-\mathrm{Y}$ zeolite," Industrial and Engineering Chemistry Research, vol. 42, no. 13, pp. 3103-3110, 2003.

[15] H. Yang and B. Tatarchuk, "Novel-doped zinc oxide sorbents for low temperature regenerable desulfurization applications," AIChE Journal, vol. 56, no. 11, pp. 2898-2904, 2010.

[16] A. Takahashi and R. T. Yang, "New adsorbents for purification: selective removal of aromatics," AIChE Journal, vol. 48, no. 7, pp. 1457-1468, 2002.

[17] J. W. Lee, H. C. Park, and H. Moon, "Adsorption and desorption of cephalosporin C on nonionic polymeric sorbents," Separation and Purification Technology, vol. 12, no. 1, pp. 111, 1997.

[18] D. Y. Cha, "Simple model of irreversible ion-exchange kinetics for sorption of antibiotics from fermentation broth," Reactive Polymers, Ion Exchangers, Sorbents, vol. 5, no. 3, pp. 269-279, 1987.

[19] M. H. L. Ribeiro and I. A. C. Ribeiro, "Recovery of erythromycin from fermentation broth by adsorption onto neutral and ion-exchange resins," Separation and Purification Technology, vol. 45, no. 3, pp. 232-239, 2005.

[20] M. Dutta, N. N. Dutta, and K. G. Bhattacharya, "Aqueous phase adsorption of certain beta-lactam antibiotics onto polymeric resins and activated carbon," Separation and Purification Technology, vol. 16, no. 3, pp. 213-224, 1999.

[21] W. S. Adriano, V. Veredas, C. C. Santana, and L. R. B. Gonçalves, "Adsorption of amoxicillin on chitosan beads: kinetics, equilibrium and validation of finite bath models," Biochemical Engineering Journal, vol. 27, no. 2, pp. 132-137, 2005.

[22] S. M. Solberg and C. C. Landry, "Adsorption of DNA into mesoporous silica," Journal of Physical Chemistry B, vol. 110, no. 31, pp. 15261-15268, 2006.

[23] B. Saoudi, N. Jammul, M. M. Chehimi, G. P. McCarthy, and S. P. Armes, "Adsorption of DNA onto polypyrrole-silica nanocomposites," Journal of Colloid and Interface Science, vol. 192, no. 1, pp. 269-273, 1997.

[24] P. Cai, Q. Huang, and X. Zhang, "Microcalorimetric studies of the effects of $\mathrm{MgCl} 2$ concentrations and $\mathrm{pH}$ on the adsorption of DNA on montmorillonite, kaolinite and goethite," Applied Clay Science, vol. 32, no. 1-2, pp. 147-152, 2006.

[25] X. Zhao and J. K. Johnson, "Simulation of adsorption of DNA on carbon nanotubes," Journal of the American Chemical Society, vol. 129, no. 34, pp. 10438-10445, 2007.

[26] X. Zhou, B. Xue, S. Bai, and Y. Sun, "Macroporous polymeric ion exchanger of high capacity for protein adsorption," Biochemical Engineering Journal, vol. 11, no. 1, pp. 13-17, 2002.

[27] Z. Ma, Y. Guan, and H. Liu, "Superparamagnetic silica nanoparticles with immobilized metal affinity ligands for protein adsorption," Journal of Magnetism and Magnetic Materials, vol. 301, no. 2, pp. 469-477, 2006.

[28] K. Yao, S. Shen, J. Yun, L. Wang, F. Chen, and X. Yu, "Protein adsorption in supermacroporous cryogels with embedded nanoparticles," Biochemical Engineering Journal, vol. 36, no. 2, pp. 139-146, 2007.

[29] X. Zhang, R. Bai, and Y. W. Tong, "Selective adsorption behaviors of proteins on polypyrrole-based adsorbents," Separation and Purification Technology, vol. 52, no. 1, pp. 161-169, 2006.

[30] X. Diao, Y. Wang, J. Zhao, and S. Zhu, "Effect of poresize of mesoporous SBA-15 on adsorption of bovine serum albumin and lysozyme protein," Chinese Journal of Chemical Engineering, vol. 18, no. 3, pp. 493-499, 2010.

[31] Y. S. Chen, C. S. Chang, and S. Y. Suen, "Protein adsorption separation using glass fiber membranes modified with short-chain organosilicon derivatives," Journal of Membrane Science, vol. 305, no. 1-2, pp. 125-135, 2007.

[32] Z. Feng, Z. Shao, J. Yao, Y. Huang, and X. Chen, "Protein adsorption and separation with chitosan-based amphoteric membranes," Polymer, vol. 50, no. 5, pp. 1257-1263, 2009.

[33] J. S. Becker, O. R. T. Thomas, and M. Franzreb, "Protein separation with magnetic adsorbents in micellar aqueous two-phase systems," Separation and Purification Technology, vol. 65, no. 1, pp. 46-53, 2009.

[34] J. Qu, "Research progress of novel adsorption processes in water purification: a review," Journal of Environmental Sciences, vol. 20, no. 1, pp. 1-13, 2008.

[35] H. Sontheimer, J. C. Crittenden, and R. S. Summers, Activated Carbon for Water Treatment, DVGW-Forschungsstelle, Karlsruhe, Germany, 2nd edition, 1988.

[36] N. H. Phan, S. Rio, C. Faur, L. Le Coq, P. Le Cloirec, and T. H. Nguyen, "Production of fibrous activated carbons from natural cellulose (jute, coconut) fibers for water treatment applications," Carbon, vol. 44, no. 12, pp. 2569-2577, 2006.

[37] S. M. Maliyekkal, S. Shukla, L. Philip, and I. M. Nambi, "Enhanced fluoride removal from drinking water by magnesia-amended activated alumina granules," Chemical Engineering Journal, vol. 140, no. 1-3, pp. 183-192, 2008.

[38] A. Bhatnagar, E. Kumar, and M. Sillanpää, "Nitrate removal from water by nano-alumina: characterization and sorption studies," Chemical Engineering Journal, vol. 163, no. 3, pp. 317-323, 2010.

[39] B. Qu, J. Zhou, X. Xiang, C. Zheng, H. Zhao, and X. Zhou, "Adsorption behavior of azo dye C. I. Acid Red 14 in aqueous solution on surface soils," Journal of Environmental Sciences, vol. 20, no. 6, pp. 704-709, 2008.

[40] S. Maity, Study on naturally occurring minerals for the removal of arsenic from groundwater, Ph.D. thesis, Jadavpur University, Kolkata, India, 2004.

[41] S. Wang and Y. Peng, "Natural zeolites as effective adsorbents in water and wastewater treatment," Chemical Engineering Journal, vol. 156, no. 1, pp. 11-24, 2010.

[42] K. H. Goh, T. T. Lim, and Z. Dong, "Application of layered double hydroxides for removal of oxyanions: a review," Water Research, vol. 42, no. 6-7, pp. 1343-1368, 2008.

[43] S. Mandal, S. Mayadevi, and B. D. Kulkarni, "Adsorption of aqueous selenite [Se(IV)] species on synthetic layered double hydroxide materials," Industrial and Engineering Chemistry Research, vol. 48, no. 17, pp. 7893-7898, 2009.

[44] K. S. Hui, C. Y. H. Chao, and S. C. Kot, "Removal of mixed heavy metal ions in wastewater by zeolite $4 \mathrm{~A}$ and residual products from recycled coal fly ash," Journal of Hazardous Materials, vol. 127, no. 1-3, pp. 89-101, 2005.

[45] C. R. Oliveira and J. Rubio, "New basis for adsorption of ionic pollutants onto modified zeolites," Minerals Engineering, vol. 20, no. 6, pp. 552-558, 2007. 
[46] M. Carmona, A. D. Lucas, J. L. Valverde, B. Velasco, and J. F. Rodríguez, "Combined adsorption and ion exchange equilibrium of phenol on Amberlite IRA-420," Chemical Engineering Journal, vol. 117, no. 2, pp. 155-160, 2006.

[47] A. Nilchi, A. A. Babalou, R. Rafiee, and H. S. Kalal, "Adsorption properties of amidoxime resins for separation of metal ions from aqueous systems," Reactive and Functional Polymers, vol. 68, no. 12, pp. 1663-1668, 2008.

[48] I. Abe, K. Hayashi, and H. Tatsumoto, "The relation between activated carbon adsorption and water quality indexes," Water Research, vol. 19, no. 9, pp. 1191-1193, 1985.

[49] I. Ali, "The quest for active carbon adsorbent substitutes: inexpensive adsorbents for toxic metal ions removal from wastewater," Separation and Purification Reviews, vol. 39, no. 3-4, pp. 95-171, 2010.

[50] B. Li, Z. Lei, and Z. Huang, "Surface-treated activated carbon for removal of aromatic compounds from water," Chemical Engineering and Technology, vol. 32, no. 5, pp. 763-770, 2009.

[51] J. Zhu, H. Liang, J. Fang, J. Zhu, and B. Shi, "Characterization of chlorinated tire-derived mesoporous activated carbon for adsorptive removal of toluene," CLEAN-Soil, Air, Water, vol. 39, no. 6, pp. 557-565, 2011.

[52] R. U. Edgehill and G. Q. Lu, "Adsorption characteristics of carbonized bark for phenol and pentachlorophenol," Journal of Chemical Technology and Biotechnology, vol. 71, no. 1, pp. 27-34, 1998.

[53] E. Ayranci and N. Hoda, "Adsorption kinetics and isotherms of pesticides onto activated carbon-cloth," Chemosphere, vol. 60, no. 11, pp. 1600-1607, 2005.

[54] E. Ayranci and N. Hoda, "Adsorption of bentazon and propanil from aqueous solutions at the high area activated carbon-cloth," Chemosphere, vol. 57, no. 8, pp. 755-762, 2004.

[55] A. R. Binupriya, M. Sathishkumar, S. H. Jung, S. H. Song, and S. I. Yun, "Bokbunja wine industry waste as precursor material for carbonization and its utilization for the removal of procion red MX-5B from aqueous solutions," CLEANSoil, Air, Water, vol. 36, no. 10-11, pp. 879-886, 2008.

[56] N. Thinakaran, P. Baskaralingam, K. V. Thiruvengada Ravi, P. Panneerselvam, and S. Sivanesan, "Adsorptive removal of acid blue 15: equilibrium and kinetic study," CLEAN-Soil, Air, Water, vol. 36, no. 9, pp. 798-804, 2008.

[57] T. Calvete, E. C. Lima, N. F. Cardoso, S. L. P. Dias, and E. S. Ribeiro, "Removal of brilliant green dye from aqueous solutions using home made activated carbons," CLEANSoil, Air, Water, vol. 38, no. 5-6, pp. 521-532, 2010.

[58] S. Sinha, K. Pandey, D. Mohan, and K. P. Singh, "Removal of fluoride from aqueous solutions by Eichhornia crassipes biomass and its carbonized form," Industrial and Engineering Chemistry Research, vol. 42, no. 26, pp. 6911-6918, 2003.

[59] X. L. Long, H. Cheng, Z. L. Xin, W. D. Xiao, W. Li, and W. K. Yuan, "Adsorption of ammonia on activated carbon from aqueous solutions," Environmental Progress, vol. 27, no. 2, pp. 225-233, 2008.

[60] Y. H. Chang, K. H. Hsieh, and F. C. Chang, "Removal of $\mathrm{Hg}^{2+}$ from aqueous solution using a novel composite carbon adsorbent," Journal of Applied Polymer Science, vol. 112, no. 4, pp. 2445-2454, 2009.

[61] C. Selomulya, V. Meeyoo, and R. Amal, "Mechanisms of $\mathrm{Cr}(\mathrm{VI})$ removal from water by various types of activated carbons," Journal of Chemical Technology and Biotechnology, vol. 74, no. 2, pp. 111-122, 1999.
[62] J. P. Chen, S. Wu, and K. H. Chong, "Surface modification of a granular activated carbon by citric acid for enhancement of copper adsorption," Carbon, vol. 41, no. 10, pp. 1979-1986, 2003.

[63] M. A. K. M. Hanafiah and W. S. W. Ngah, "Preparation, characterization and adsorption mechanism of $\mathrm{Cu}$ (II) onto protonated rubber leaf powder," CLEAN-Soil, Air, Water, vol. 37, no. 9, pp. 696-703, 2009.

[64] K. A. Krishnan, A. Sheela, and T. S. Anirudhan, "Kinetic and equilibrium modeling of liquid-phase adsorption of lead and lead chelates on activated carbons," Journal of Chemical Technology and Biotechnology, vol. 78, no. 6, pp. 642-653, 2003.

[65] G. Crini, "Recent developments in polysaccharide-based materials used as adsorbents in wastewater treatment," Progress in Polymer Science, vol. 30, no. 1, pp. 38-70, 2005.

[66] G. Crini, "Non-conventional low-cost adsorbents for dye removal: a review," Bioresource Technology, vol. 97, no. 9, pp. 1061-1085, 2006.

[67] C. Jeon, I. W. Nah, and K. Y. Hwang, "Adsorption of heavy metals using magnetically modified alginic acid," Hydrometallurgy, vol. 86, no. 3-4, pp. 140-146, 2007.

[68] J. Kumar, C. Balomajumder, and P. Mondal, "Application of agro-based biomasses for zinc removal from wastewater-a review," CLEAN—Soil, Air, Water, vol. 39, no. 7, pp. 641-652, 2011.

[69] C. Zevenbergen, L. P. van Reeuwijk, G. Frapporti, R. J. Louws, and R. D. Schuiling, "A simple method for defluoridation of drinking water at village level by adsorption on Ando soil in Kenya," Science of the Total Environment, vol. 188, no. 2-3, pp. 225-232, 1996.

[70] W. Jiang, S. Zhang, X. Q. Shan, M. Feng, Y. G. Zhu, and R. G. McLaren, "Adsorption of arsenate on soils. Part 1: laboratory batch experiments using 16 Chinese soils with different physiochemical properties," Environmental Pollution, vol. 138, no. 2, pp. 278-284, 2005.

[71] S. K. Maji, A. Pal, and T. Pal, "Arsenic removal from reallife groundwater by adsorption on laterite soil," Journal of Hazardous Materials, vol. 151, no. 2-3, pp. 811-820, 2008.

[72] J. L. Dai, M. Zhang, and Y. G. Zhu, "Adsorption and desorption of iodine by various Chinese soils I. Iodate," Environment International, vol. 30, no. 4, pp. 525-530, 2004.

[73] H. Q. Hu, J. Z. He, X. Y. Li, and F. Liu, "Effect of several organic acids on phosphate adsorption by variable charge soils of central China," Environment International, vol. 26, no. 5-6, pp. 353-358, 2001.

[74] P. R. Shukla, S. Wang, H. M. Ang, and M. O. Tadé, "Synthesis, characterisation, and adsorption evaluation of carbonnatural-zeolite composites," Advanced Powder Technology, vol. 20, no. 3, pp. 245-250, 2009.

[75] Y. H. Xu, T. Nakajima, and A. Ohki, "Adsorption and removal of arsenic(V) from drinking water by aluminum-loaded Shirasu-zeolite," Journal of Hazardous Materials, vol. 92, no. 3, pp. 275-287, 2002.

[76] X. Ren, C. Chen, M. Nagatsu, and X. Wang, "Carbon nanotubes as adsorbents in environmental pollution management: a review," Chemical Engineering Journal, vol. 170, pp. 395-410, 2011.

[77] Y. H. Li, S. Wang, A. Cao et al., "Adsorption of fluoride from water by amorphous alumina supported on carbon nanotubes," Chemical Physics Letters, vol. 350, no. 5-6, pp. 412-416, 2001. 
[78] Y. S. Ok, J. E. Yang, Y. S. Zhang, S. J. Kim, and D. Y. Chung, "Heavy metal adsorption by a formulated zeolite-Portland cement mixture," Journal of Hazardous Materials, vol. 147, no. 1-2, pp. 91-96, 2007.

[79] C. D. Johnson and F. Worrall, "Novel granular materials with microcrystalline active surfaces-Waste water treatment applications of zeolite/vermiculite composites," Water Research, vol. 41, no. 10, pp. 2229-2235, 2007.

[80] S. Mandal and S. Mayadevi, "Cellulose supported layered double hydroxides for the adsorption of fluoride from aqueous solution," Chemosphere, vol. 72, no. 6, pp. 995-998, 2008.

[81] J. Hao, M. J. Han, C. Wang, and X. Meng, "Enhanced removal of arsenite from water by a mesoporous hybrid materialthiol-functionalized silica coated activated alumina," Microporous and Mesoporous Materials, vol. 124, no. 1-3, pp. 1-7, 2009.

[82] Z. Li, S. Deng, G. Yu, J. Huang, and V. C. Lim, "As(V) and As(III) removal from water by a Ce-Ti oxide adsorbent: behavior and mechanism," Chemical Engineering Journal, vol. 161, no. 1-2, pp. 106-113, 2010.

[83] F. P. Cuperus, "Membrane processes in agro-food state-ofthe-art and new opportunities," Separation and Purification Technology, vol. 14, no. 1-3, pp. 233-239, 1998.

[84] B. Girard and L. R. Fukumoto, "Membrane processing of fruit juices and beverages: a review," Critical Reviews in Food Science and Nutrition, vol. 40, no. 2, pp. 91-157, 2000.

[85] R. van Reis and A. Zydney, "Membrane separations in biotechnology," Current Opinion in Biotechnology, vol. 12, no. 2, pp. 208-211, 2001.

[86] C. Charcosset, "Membrane processes in biotechnology: an overview," Biotechnology Advances, vol. 24, no. 5, pp. 482 492, 2006.

[87] F. T. Awadalla and A. Kumar, "Opportunities for membrane technologies in the treatment of mining and mineral process streams and effluents," Separation Science and Technology, vol. 29, no. 10, pp. 1231-1249, 1994.

[88] W. Doyen, "Latest developments in ultrafiltration for largescale drinking water applications," Desalination, vol. 113, no. 2-3, pp. 165-177, 1997.

[89] A. Bottino, C. Capannelli, A. Del Borghi, M. Colombino, and O. Conio, "Water treatment for drinking purpose: ceramic microfiltration application," Desalination, vol. 141, no. 1, pp. 75-79, 2001.

[90] P. Lipp, M. Witte, G. Baldauf, and A. A. Povorov, “Treatment of reservoir water with a backwashable MF/UF spiral wound membrane," Desalination, vol. 179, no. 1-3, pp. 83-94, 2005.

[91] J. Mueller, Y. Cen, and R. H. Davis, "Crossflow microfiltration of oily water," Journal of Membrane Science, vol. 129, no. 2, pp. 221-235, 1997.

[92] H. Liang, W. Gong, and G. Li, "Performance evaluation of water treatment ultrafiltration pilot plants treating algae-rich reservoir water," Desalination, vol. 221, no. 1-3, pp. 345-350, 2008.

[93] S. S. Madaeni, A. G. Fane, and G. S. Grohmann, "Virus removal from water and wastewater using membranes," Journal of Membrane Science, vol. 102, no. 1-3, pp. 65-75, 1995.

[94] L. L. Zhang, D. Yang, Z. J. Zhong, and P. Gu, "Application of hybrid coagulation-microfiltration process for treatment of membrane backwash water from waterworks," Separation and Purification Technology, vol. 62, no. 2, pp. 415-422, 2008.
[95] P. Drogui, S. Elmaleh, M. Rumeau, C. Bernard, and A. Rambaud, "Hybride process, microfiltration-electroperoxidation, for water treatment," Journal of Membrane Science, vol. 186, no. 1, pp. 123-132, 2001.

[96] B. Schlichter, V. Mavrov, and H. Chmiel, "Study of a hybrid process combining ozonation and microfiltration/ultrafiltration for drinking water production from surface water," Desalination, vol. 168, no. 1-3, pp. 307-317, 2004.

[97] F. Malek, J. L. Harris, and F. A. Roddick, "Interrelationship of photooxidation and microfiltration in drinking water treatment," Journal of Membrane Science, vol. 281, no. 1-2, pp. 541-547, 2006.

[98] Y. T. Tsai, Y. H. Weng, A. Y. C. Lin, and K. C. Li, "Electromicrofiltration treatment of water containing natural organic matter and inorganic particles," Desalination, vol. 267, no. 23, pp. 133-138, 2011.

[99] F. V. Kosikowski and V. V. Mistry, "Microfiltration, ultrafiltration, and centrifugation separation and sterilization processes for improving milk and cheese quality," Journal of Dairy Science, vol. 73, pp. 1411-1419, 1990.

[100] P. Morin, M. Britten, R. Jiménez-Flores, and Y. Pouliot, "Microfiltration of buttermilk and washed cream buttermilk for concentration of milk fat globule membrane components," Journal of Dairy Science, vol. 90, no. 5, pp. 2132-2140, 2007.

[101] R. S. Barhate, R. Subramanian, K. E. Nandini, and H. U. Hebbar, "Processing of honey using polymeric microfiltration and ultrafiltration membranes," Journal of Food Engineering, vol. 60, no. 1, pp. 49-54, 2003.

[102] F. Vaillant, A. Millan, M. Dornier, M. Decloux, and M. Reynes, "Strategy for economical optimization of the clarification of pulpy fruit juices using crossflow microfiltration," Journal of Food Engineering, vol. 48, no. 1, pp. 83-90, 2001.

[103] S. Mondal, A. Cassano, F. Tasselli, and S. De, "A generalized model for clarification of fruit juice during ultrafiltration under total recycle and batch mode," Journal of Membrane Science, vol. 366, no. 1-2, pp. 295-303, 2011.

[104] M. Hamachi, B. B. Gupta, and R. B. Aim, "Ultrafiltration: a means for decolorization of cane sugar solution," Separation and Purification Technology, vol. 30, no. 3, pp. 229-239, 2003.

[105] B. K. Nelson and D. M. Barbano, "A microfiltration process to maximize removal of serum proteins from skim milk before cheese making," Journal of Dairy Science, vol. 88, no. 5, pp. 1891-1900, 2005.

[106] T. Y. Wu, A. W. Mohammad, J. M. Jahim, and N. Anuar, "Palm oil mill effluent (POME) treatment and bioresources recovery using ultrafiltration membrane: effect of pressure on membrane fouling," Biochemical Engineering Journal, vol. 35, no. 3, pp. 309-317, 2007.

[107] M. D. Afonso and R. Bórquez, "Review of the treatment of seafood processing wastewaters and recovery of proteins therein by membrane separation processes-prospects of the ultrafiltration of wastewaters from the fish meal industry," Desalination, vol. 142, no. 1, pp. 29-45, 2002.

[108] Y. M. Lo, D. Cao, S. Argin-Soysal, J. Wang, and T. S. Hahm, "Recovery of protein from poultry processing wastewater using membrane ultrafiltration," Bioresource Technology, vol. 96, no. 6, pp. 687-698, 2005.

[109] Y. Li, A. Shahbazi, and C. T. Kadzere, "Separation of cells and proteins from fermentation broth using ultrafiltration," Journal of Food Engineering, vol. 75, no. 4, pp. 574-580, 2006. 
[110] C. W. Cho, D. Y. Lee, and C. W. Kim, "Concentration and purification of soluble pectin from mandarin peels using crossflow microfiltration system," Carbohydrate Polymers, vol. 54, no. 1, pp. 21-26, 2003.

[111] V. G. Molina and A. Casañas, "Reverse osmosis, a key technology in combating water scarcity in Spain," Desalination, vol. 250, no. 3, pp. 950-955, 2010.

[112] L. Malaeb and G. M. Ayoub, "Reverse osmosis technology for water treatment: state of the art review," Desalination, vol. 267, no. 1, pp. 1-8, 2011

[113] A. Almulla, M. Eid, P. Côté, and J. Coburn, "Developments in high recovery brackish water desalination plants as part of the solution yp water quantity problems," Desalination, vol. 153, no. 1-3, pp. 237-243, 2003.

[114] J. C. Schrotter, S. Rapenne, J. Leparc, P. J. Remize, and S. Casas, "Current and emerging developments in desalination with reverse osmosis membrane systems," in Comprehensive Membrane Science and Engineering, E. Drioli and L. Giorno, Eds., chapter 2.03, pp. 35-65, Elsevier, New York, NY, USA, 2010.

[115] M. Liu, S. Yu, J. Tao, and C. Gao, "Preparation, structure characteristics and separation properties of thin-film composite polyamide-urethane seawater reverse osmosis membrane," Journal of Membrane Science, vol. 325, no. 2, pp. 947-956, 2008.

[116] M. Duan, Z. Wang, J. Xu, J. Wang, and S. Wang, "Influence of hexamethyl phosphoramide on polyamide composite reverse osmosis membrane performance," Separation and Purification Technology, vol. 75, no. 2, pp. 145-155, 2010.

[117] J. C. Kruithof, J. C. Schippers, P. C. Kamp, H. C. Folmer, and J. A. M. H. Hofman, "Integrated multi-objective membrane systems for surface water treatment: pretreatment of reverse osmosis by conventional treatment and ultrafiltration," Desalination, vol. 117, no. 1-3, pp. 37-48, 1998.

[118] A. M'nif, S. Bouguecha, B. Hamrouni, and M. Dhahbi, "Coupling of membrane processes for brackish water desalination," Desalination, vol. 203, no. 1-3, pp. 331-336, 2007.

[119] N. Prihasto, Q. F. Liu, and S. H. Kim, "Pre-treatment strategies for seawater desalination by reverse osmosis system," Desalination, vol. 249, no. 1, pp. 308-316, 2009.

[120] K. L. Tu, L. D. Nghiem, and A. R. Chivas, "Boron removal by reverse osmosis membranes in seawater desalination applications," Separation and Purification Technology, vol. 75, no. 2, pp. 87-101, 2010.

[121] X. Chai, G. Chen, P. L. Yue, and Y. Mi, "Pilot scale membrane separation of electroplating waste water by reverse osmosis," Journal of Membrane Science, vol. 123, no. 2, pp. 235-242, 1997.

[122] P. Čuda, P. Pospíšil, and J. Tenglerová, "Reverse osmosis in water treatment for boilers," Desalination, vol. 198, no. 1-3, pp. 41-46, 2006.

[123] M. Belkacem, S. Bekhti, and K. Bensadok, "Groundwater treatment by reverse osmosis," Desalination, vol. 206, no. 1-3, pp. 100-106, 2007.

[124] M. Melo, H. Schluter, J. Ferreira, R. Magda, A. Júnior, and O. de Aquino, "Advanced performance evaluation of a reverse osmosis treatment for oilfield produced water aiming reuse," Desalination, vol. 250, no. 3, pp. 1016-1018, 2010.

[125] M. K. H. Liew, S. Tanaka, and M. Morita, "Separation and purification of lactic acid: fundamental studies on the reverse osmosis down-stream process," Desalination, vol. 101, no. 3, pp. 269-277, 1995.
[126] V. V. Goncharuk, D. D. Kucheruk, V. M. Kochkodan, and V. P. Badekha, "Removal of organic substances from aqueous solutions by reagent enhanced reverse osmosis," Desalination, vol. 143, no. 1, pp. 45-51, 2002.

[127] F. Liu, G. Zhang, Q. Meng, and H. Zhang, "Performance of nanofiltration and reverse osmosis membranes in metal effluent treatment," Chinese Journal of Chemical Engineering, vol. 16, no. 3, pp. 441-445, 2008.

[128] J. Weißbrodt, M. Manthey, B. Ditgens, G. Laufenberg, and B. Kunz, "Separation of aqueous organic multi-component solutions by reverse osmosis-development of a mass transfer model," Desalination, vol. 133, no. 1, pp. 65-74, 2001.

[129] C. H. Liang, "Separation properties of high temperature reverse osmosis membranes for silica removal and boric acid recovery," Journal of Membrane Science, vol. 246, no. 2, pp. 127-135, 2005.

[130] M. Sadrzadeh and T. Mohammadi, "Sea water desalination using electrodialysis," Desalination, vol. 221, no. 1-3, pp. 440-447, 2008.

[131] M. Sadrzadeh and T. Mohammadi, "Treatment of sea water using electrodialysis: current efficiency evaluation," Desalination, vol. 249, no. 1, pp. 279-285, 2009.

[132] S. K. Nataraj, K. M. Hosamani, and T. M. Aminabhavi, "Potential application of an electrodialysis pilot plant containing ion-exchange membranes in chromium removal," Desalination, vol. 217, no. 1-3, pp. 181-190, 2007.

[133] K. Takahashi, K. Umehara, G. P. T. Cruz, S. Nil, and F. Kawaizumi, "Mutual separation of two monovalent metal ions by multistage electrodialysis," Chemical Engineering Science, vol. 60, no. 3, pp. 727-734, 2005.

[134] F. Hell, J. Lahnsteiner, H. Frischherz, and G. Baumgartner, "Experience with full-scale electrodialysis for nitrate and hardness removal," Desalination, vol. 117, no. 1-3, pp. 173180, 1998.

[135] L. J. Banasiak and A. I. Schäfer, "Removal of boron, fluoride and nitrate by electrodialysis in the presence of organic matter," Journal of Membrane Science, vol. 334, no. 1-2, pp. 101-109, 2009.

[136] T. Sata, "Studies on ion exchange membranes with permselectivity for specific ions in electrodialysis," Journal of Membrane Science, vol. 93, no. 2, pp. 117-135, 1994.

[137] M. Demircioglu, N. Kabay, I. Kurucaovali, and E. Ersoz, "Demineralization by electrodialysis (ED)—separation performance and cost comparison for monovalent salts," Desalination, vol. 153, no. 1-3, pp. 329-333, 2003.

[138] R. Audinos, A. Nassr-Allah, J. R. Alvarez, J. L. Andres, and R. Alvarez, "Electrodialysis in the separation of dilute aqueous solutions of sulfuric and nitric acids," Journal of Membrane Science, vol. 76, no. 2-3, pp. 147-156, 1993.

[139] G. S. Luo, X. Y. Shan, X. Qi, and Y. C. Lu, "Two-phase electroelectrodialysis for recovery and concentration of citric acid," Separation and Purification Technology, vol. 38, no. 3, pp. 265-271, 2004.

[140] F. S. Rohman, M. R. Othman, and N. Aziz, "Modeling of batch electrodialysis for hydrochloric acid recovery," Chemical Engineering Journal, vol. 162, no. 2, pp. 466-479, 2010.

[141] B. van der Bruggen, A. Koninckx, and C. Vandecasteele, "Separation of monovalent and divalent ions from aqueous solution by electrodialysis and nanofiltration," Water Research, vol. 38, no. 5, pp. 1347-1353, 2004.

[142] P. V. Vyas, B. G. Shah, G. S. Trivedi, P. M. Gaur, P. Ray, and S. K. Adhikary, "Separation of inorganic and organic acids 
from glyoxal by electrodialysis," Desalination, vol. 140, no. 1, pp. 47-54, 2001.

[143] H. Habe, T. Fukuoka, D. Kitamoto, and K. Sakaki, “Application of electrodialysis to glycerate recovery from a glycerol containing model solution and culture broth," Journal of Bioscience and Bioengineering, vol. 107, no. 4, pp. 425-428, 2009.

[144] T. V. Eliseeva, V. A. Shaposhnik, E. V. Krisilova, and A. E. Bukhovets, "Transport of basic amino acids through the ionexchange membranes and their recovery by electrodialysis," Desalination, vol. 241, no. 1-3, pp. 86-90, 2009.

[145] X. Zhang, W. Lu, H. Ren, and W. Cong, "Recovery of glutamic acid from isoelectric supernatant using electrodialysis," Separation and Purification Technology, vol. 55, no. 2, pp. 274-280, 2007.

[146] G. Atungulu, S. Koide, S. Sasaki, and W. Cao, "Ion-exchange membrane mediated electrodialysis of scallop broth: ion, free amino acid and heavy metal profiles," Journal of Food Engineering, vol. 78, no. 4, pp. 1285-1290, 2007.

[147] L. Yu, A. Lin, L. Zhang, C. Chen, and W. Jiang, "Application of electrodialysis to the production of Vitamin C," Chemical Engineering Journal, vol. 78, no. 2-3, pp. 153-157, 2000.

[148] E. M. van der Ent, P. van Hee, J. T. F. Keurentjes, K. van’t Riet, and A. van der Padt, "Multistage electrodialysis for largescale separation of racemic mixtures," Journal of Membrane Science, vol. 204, no. 1-2, pp. 173-184, 2002.

[149] T. Xu and C. Huang, "Electrodialysis-Based separation technologies: a critical review," AIChE Journal, vol. 54, no. 12, pp. 3147-3159, 2008.

[150] L. Firdaous, P. Dhulster, J. Amiot et al., "Concentration and selective separation of bioactive peptides from an alfalfa white protein hydrolysate by electrodialysis with ultrafiltration membranes," Journal of Membrane Science, vol. 329, no. 1-2, pp. 60-67, 2009.

[151] L. Bazinet, J. Amiot, J. F. Poulin, D. Labbe, and D. Tremblay, "Process and system for separation of organic charged compounds," International Patent WO 2005/082495A1, 2005.

[152] K. Nagai, "Fundamentals and perspectives for pervaporation," in Comprehensive Membrane Science and Engineering, chapter 2.10, pp. 243-271, 2010.

[153] L. Hitchens, L. M. Vane, and F. R. Alvarez, "VOC removal from water and surfactant solutions by pervaporation: a pilot study," Separation and Purification Technology, vol. 24, no. 12, pp. 67-84, 2001.

[154] M. Peng, L. M. Vane, and S. X. Liu, "Recent advances in VOCs removal from water by pervaporation," Journal of Hazardous Materials, vol. 98, no. 1-3, pp. 69-90, 2003.

[155] H. O. E. Karlsson and G. Tragardh, "Pervaporation of dilute organic-waters mixtures. A literature review on modelling studies and applications to aroma compound recovery," Journal of Membrane Science, vol. 76, no. 2-3, pp. 121-146, 1993.

[156] A. Hasanoğlu, Y. Salt, S. Keleşer, S. Özkan, and S. Dinçer, "Pervaporation separation of organics from multicomponent aqueous mixtures," Chemical Engineering and Processing, vol. 46, no. 4, pp. 300-306, 2007.

[157] B. Smitha, D. Suhanya, S. Sridhar, and M. Ramakrishna, "Separation of organic-organic mixtures by pervaporationa review," Journal of Membrane Science, vol. 241, no. 1, pp. $1-21,2004$.

[158] B. K. Dutta and S. K. Sikdar, "Separation of azeotropic organic liquid mixtures by pervaporation," AIChE Journal, vol. 37 , no. 4, pp. 581-588, 1991.
[159] A. Hasanoğlu, Y. Salt, S. Keleşer, S. Özkan, and S. Dinçer, "Pervaporation separation of ethyl acetate-ethanol binary mixtures using polydimethylsiloxane membranes," Chemical Engineering and Processing, vol. 44, no. 3, pp. 375-381, 2005.

[160] M. Wessling, U. Werner, and S. T. Hwang, "Pervaporation of aromatic C8-isomers," Journal of Membrane Science, vol. 57, no. 2-3, pp. 257-270, 1991.

[161] H. L. Chen, L. G. Wu, J. Tan, and C. L. Zhu, "PVA membrane filled $\beta$-cyclodextrin for separation of isomeric xylenes by pervaporation," Chemical Engineering Journal, vol. 78, no. 23, pp. 159-164, 2000.

[162] F. Lipnizki, J. Olsson, and G. Trägårdh, "Scale-up of pervaporation for the recovery of natural aroma compounds in the food industry. Part 1: simulation and performance," Journal of Food Engineering, vol. 54, no. 3, pp. 183-195, 2002.

[163] X. Feng and R. Y. M. Huang, "Pervaporation with chitosan membranes. I. Separation of water from ethylene glycol by a chitosan/polysulfone composite membrane," Journal of Membrane Science, vol. 116, no. 1, pp. 67-76, 1996.

[164] P. Shao and R. Y. M. Huang, "Polymeric membrane pervaporation," Journal of Membrane Science, vol. 287, no. 2, pp. 162-179, 2007.

[165] S. D. Bhat and T. M. Aminabhavi, "Pervaporation separation using sodium alginate and its modified membranes-a review," Separation and Purification Reviews, vol. 36, no. 3, pp. 203-229, 2007.

[166] S. G. Adoor, L. S. Manjeshwar, B. V. Kumar Naidu, M. Sairam, and T. M. Aminabhavi, "Poly(vinyl alcohol)/poly(methyl methacrylate) blend membranes for pervaporation separation of water + isopropanol and water +1 ,4-dioxane mixtures," Journal of Membrane Science, vol. 280, no. 1-2, pp. 594-602, 2006.

[167] M. G. Mali, V. T. Magalad, G. S. Gokavi, T. M. Aminabhavi, and K. V. S. N. Raju, "Pervaporation separation of isopropanol-water mixtures using mixed matrix blend membranes of poly(vinyl alcohol)/poly(vinyl pyrrolidone) loaded with phosphomolybdic acid," Journal of Applied Polymer Science, vol. 121, no. 2, pp. 711-719, 2011.

[168] Y. Wang, L. Yang, G. Luo, and Y. Dai, "Preparation of cellulose acetate membrane filled with metal oxide particles for the pervaporation separation of methanol/methyl tertbutyl ether mixtures," Chemical Engineering Journal, vol. 146, no. 1, pp. 6-10, 2009.

[169] S. L. Wee, C. T. Tye, and S. Bhatia, "Membrane separation process-Pervaporation through zeolite membrane," Separation and Purification Technology, vol. 63, no. 3, pp. 500-516, 2008.

[170] W. Kujawski, A. Warszawski, W. Ratajczak, T. Porębski, W. Capała, and I. Ostrowska, "Application of pervaporation and adsorption to the phenol removal from wastewater," Separation and Purification Technology, vol. 40, no. 2, pp. 123-132, 2004.

[171] G. S. Luo, M. Niang, and P. Schaetzel, "Separation of ethyl tert-butyl ether-ethanol by combined pervaporation and distillation," Chemical Engineering Journal, vol. 68, no. 2-3, pp. 139-143, 1997.

[172] S. Assabumrungrat, J. Phongpatthanapanich, P. Praserthdam, T. Tagawa, and S. Goto, "Theoretical study on the synthesis of methyl acetate from methanol and acetic acid in pervaporation membrane reactors: effect of continuous-flow modes," Chemical Engineering Journal, vol. 95, no. 1, pp. 5765, 2003.

[173] G. J. S. van der Gulik, R. E. G. Janssen, J. G. Wijers, and J. T. F. Keurentjes, "Hydrodynamics in a ceramic pervaporation 
membrane reactor for resin production," Chemical Engineering Science, vol. 56, no. 2, pp. 371-379, 2001.

[174] B. van der Bruggen, "Pervaporation membrane reactors," in Comprehensive Membrane Science and Engineering, vol. 3, pp. 135-163, 2010.

[175] B. G. Park and T. T. Tsotsis, "Models and experiments with pervaporation membrane reactors integrated with an adsorbent system," Chemical Engineering and Processing, vol. 43, no. 9, pp. 1171-1180, 2004.

[176] C. Liu, X. Xu, Q. Wang, and J. Chen, "Mathematical model for DNA separation by capillary electrophoresis in entangled polymer solutions," Journal of Chromatography A, vol. 1142, no. 2, pp. 222-230, 2007.

[177] A. R. Piergiovanni, "Extraction and separation of watersoluble proteins from different wheat species by acidic capillary electrophoresis," Journal of Agricultural and Food Chemistry, vol. 55, no. 10, pp. 3850-3856, 2007.

[178] G. Gübitz and M. G. Schmid, "Chiral separation by chromatographic and electromigration techniques. A review," Biopharmaceutics and Drug Disposition, vol. 22, no. 7-8, pp. 291-336, 2001.

[179] M. J. Clifton, H. Roux-De Balmann, and V. Sanchez, "Protein separation by continuous-flow electrophoresis in microgravity," AIChE Journal, vol. 42, no. 7, pp. 2069-2078, 1996.

[180] S. L. Zhai, G. S. Luo, and J. G. Liu, "Selective recovery of amino acids by aqueous two-phase electrophoresis," Chemical Engineering Journal, vol. 83, no. 1, pp. 55-59, 2001.

[181] T. Guerin, A. Astruc, and M. Astruc, "Speciation of arsenic and selenium compounds by HPLC hyphenated to specific detectors: a review of the main separation techniques," Talanta, vol. 50, no. 1, pp. 1-24, 1999.

[182] T. Burnouf and M. Radosevich, "Affinity chromatography in the industrial purification of plasma proteins for therapeutic use," Journal of Biochemical and Biophysical Methods, vol. 49, no. $1-3$, pp. 575-586, 2001.

[183] W. Guo and E. Ruckenstein, "Separation and purification of horseradish peroxidase by membrane affinity chromatography," Journal of Membrane Science, vol. 211, no. 1, pp. 101111, 2003.

[184] M. Yılmaz, G. Bayramoğlu, and M. Y. Arica, "Separation and purification of lysozyme by Reactive Green 19 immobilised membrane affinity chromatography," Food Chemistry, vol. 89, no. 1, pp. 11-18, 2005.

[185] V. Gaberc-Porekar and V. Menart, "Perspectives of immobilized-metal affinity chromatography," Journal of Biochemical and Biophysical Methods, vol. 49, no. 1-3, pp. 335-360, 2001.

[186] G. Feng, D. Hu, L. Yang, Y. Cui, X. A. Cui, and H. Li, "Immobilized-metal affinity chromatography adsorbent with paramagnetism and its application in purification of histidine-tagged proteins," Separation and Purification Technology, vol. 74, no. 2, pp. 253-260, 2010.

[187] E. E. G. Rojas, J. S. Dos Reis Coimbra, L. A. Minim, A. D. G. Zuniga, S. H. Saraiva, and V. P. R. Minim, "Size-exclusion chromatography applied to the purification of whey proteins from the polymeric and saline phases of aqueous two-phase systems," Process Biochemistry, vol. 39, no. 11, pp. 1751-1759, 2004.

[188] D. A. Horneman, M. Ottens, J. T. F. Keurentjes, and L. A. M. van der Wielen, "Surfactant-aided size-exclusion chromatography for the purification of immunoglobulin G," Journal of Chromatography A, vol. 1157, no. 1-2, pp. 237-245, 2007.
[189] N. Suematsu, K. Okamoto, and F. Isohashi, "Simple and unique purification by size-exclusion chromatography for an oligomeric enzyme, rat liver cytosolic acetyl-coenzyme A hydrolase," Journal of Chromatography B, vol. 790, no. 1-2, pp. 239-244, 2003.

[190] G. B. Irvine, "High-performance size-exclusion chromatography of peptides," Journal of Biochemical and Biophysical Methods, vol. 56, no. 1-3, pp. 233-242, 2003.

[191] J. Strube, R. Gärtner, and M. Schulte, "Process development of product recovery and solvent recycling steps of chromatographic separation processes," Chemical Engineering Journal, vol. 85, no. 2-3, pp. 273-288, 2002.

[192] L. S. Pais, J. M. Loureiro, and A. E. Rodrigues, "Modeling strategies for enantiomers separation by SMB chromatography," AIChE Journal, vol. 44, no. 3, pp. 561-569, 1998.

[193] C. Migliorini, M. Mazzotti, G. Zenoni, and M. Morbidelli, "Shortcut experimental method for designing chiral SMB separations," AIChE Journal, vol. 48, no. 1, pp. 69-77, 2002.

[194] P. S. Gomes, M. Zabkova, M. Zabka, M. Minceva, and A. E. Rodrigues, "Separation of chiral mixtures in real SMB units: the FlexSMB-LSRE," AIChE Journal, vol. 56, pp. 125-142, 2010.

[195] O. Ludemann-Hombourger, R. M. Nicoud, and M. Bailly, "The "VARICOL" process: a new multicolumn continuous chromatographic process," Separation Science and Technology, vol. 35, no. 12, pp. 1829-1862, 2000.

[196] O. Ludemann-Hombourger, G. Pigorini, R. M. Nicoud, D. S. Ross, and G. Terfloth, "Application of the "VARICOL" process to the separation of the isomers of the SB-553261 racemate," Journal of Chromatography A, vol. 947, no. 1, pp. 59-68, 2002.

[197] S. R. Perrin, W. Hauck, E. Ndzie et al., "Purification of difluoromethylornithine by global process optimization: coupling of chemistry and chromatography with enantioselective crystallization," Organic Process Research and Development, vol. 11, no. 5, pp. 817-824, 2007.

[198] M. Minceva, P. S. Gomes, V. Meshko, and A. E. Rodrigues, "Simulated moving bed reactor for isomerization and separation of p-xylene," Chemical Engineering Journal, vol. 140, no. 1-3, pp. 305-323, 2008.

[199] M. Lukáč and Z. Peřina, "A dynamic model of physical processes in chromatographic glucose-fructose separation," Chemical Engineering Science, vol. 46, no. 4, pp. 959-965, 1991.

[200] D. C. S. Azevedo and A. E. Rodrigues, "Fructose-glucose separation in a SMB pilot unit: modeling, simulation, design, and operation," AIChE Journal, vol. 47, no. 9, pp. 2042-2051, 2001.

[201] H. J. Subramani, K. Hidajat, and A. K. Ray, "Optimization of simulated moving bed and varicol processes for glucosefructose separation," Chemical Engineering Research and Design, vol. 81, no. 5, pp. 549-567, 2003.

[202] S. Imamoglu, "Simulated moving bed chromatography (SMB) for application in bioseparation," Advances in Biochemical Engineering/Biotechnology, vol. 76, pp. 211-231, 2002.

[203] J. Andersson and B. Mattiasson, "Simulated moving bed technology with a simplified approach for protein purification: separation of lactoperoxidase and lactoferrin from whey protein concentrate," Journal of Chromatography A, vol. 1107, no. 1-2, pp. 88-95, 2006.

[204] P. Li, G. Xiu, and A. E. Rodrigues, "Proteins separation and purification by salt gradient ion-exchange SMB," AIChE Journal, vol. 53, no. 9, pp. 2419-2431, 2007. 
[205] D. J. Wu, Y. Xie, Z. Ma, and N. H. L. Wang, "Design of simulated moving bed chromatography for amino acid separations," Industrial and Engineering Chemistry Research, vol. 37, no. 10, pp. 4023-4035, 1998.

[206] N. Gottschlich and V. Kasche, "Purification of monoclonal antibodies by simulated moving-bed chromatography," Journal of Chromatography A, vol. 765, no. 2, pp. 201-206, 1997.

[207] A. Geisser, T. Hendrich, G. Boehm, and B. Stahl, "Separation of lactose from human milk oligosaccharides with simulated moving bed chromatography," Journal of Chromatography A, vol. 1092, no. 1-2, pp. 17-23, 2005.

[208] G. Paredes, M. Mazzotti, J. Stadler, S. Makart, and M. Morbidelli, "SMB operation for three-fraction separations: purification of plasmid DNA," Adsorption, vol. 11, no. 1, pp. 841-845, 2005.

[209] Q. Du, P. Wu, and Y. Ito, "Low-speed rotary countercurrent chromatography using a convoluted multilayer helical tube for industrial separation," Analytical Chemistry, vol. 72, no. 14 , pp. 3363-3365, 2000.

[210] J. Chen, G. X. Ma, and D. Q. Li, "HPCPC separation of proteins using polyethylene glycol-potassium phosphate aqueous two-phase," Preparative Biochemistry and Biotechnology, vol. 29, no. 4, pp. 371-383, 1999.

[211] A. E. Herr, J. I. Molho, J. G. Santiago, M. G. Mungal, T. W. Kenny, and M. G. Garguilo, "Electroosmotic capillary flow with nonuniform zeta potential," Analytical Chemistry, vol. 72, no. 5, pp. 1053-1057, 2000.

[212] E. Bartow and R. H. Jebens, "Purification of water by electroosmosis," Industrial \& Engineering Chemistry, vol. 22, pp. 1020-1022, 1930.

[213] C. S. Grant, E. J. Clayfield, and M. J. Matteson, "Surfactant enhanced electro-osmotic separation of iron oxide ultrafines," Colloids and Surfaces, vol. 65, no. 4, pp. 257-272, 1992.

[214] P. J. Buijs, A. J. G. van Diemen, and H. N. Stein, "Efficient dewatering of waterworks sludge by electroosmosis," Colloids and Surfaces A, vol. 85, no. 1, pp. 29-36, 1994.

[215] S. Al-Asheh, R. Jumah, F. Banat, and K. Al-Zou'bi, "Direct current electroosmosis dewatering of tomato paste suspension," Food and Bioproducts Processing, vol. 82, no. 3, pp. 193 200, 2004.

[216] D. S. Schultz, "Electro-osmotic technology for soil remediation: laboratory results, field trial, and economic modeling," Journal of Hazardous Materials, vol. 55, pp. 81-91, 1997.

[217] S. Laursen and J. B. Jensen, "Electroosmosis in filter cakes of activated sludge," Water Research, vol. 27, no. 5, pp. 777-783, 1993.

[218] K. Sarangi and A. K. Pattanaik, "A hybrid process for recovering copper from dilute solutions," Separation Science and Technology, vol. 42, no. 1, pp. 89-102, 2007.

[219] J. Y. Tian, Z. L. Chen, J. Nan, H. Liang, and G. B. Li, "Integrative membrane coagulation adsorption bioreactor (MCABR) for enhanced organic matter removal in drinking water treatment," Journal of Membrane Science, vol. 352, no. 1-2, pp. 205-212, 2010.

[220] Y. C. Wang, M. H. Choi, and J. Han, "Two-dimensional protein separation with advanced sample and buffer isolation using microfluidic valves," Analytical Chemistry, vol. 76, no. 15, pp. 4426-4431, 2004.

[221] P. B. Spoor, L. Grabovska, L. Koene, L. J. J. Janssen, and W. R. Ter Veen, "Pilot scale deionisation of a galvanic nickel solution using a hybrid ion-exchange/electrodialysis system," Chemical Engineering Journal, vol. 89, no. 1-3, pp. 193-202, 2002.
[222] A. L. Ahmad and S. W. Puasa, "Reactive dyes decolourization from an aqueous solution by combined coagulation/ micellar-enhanced ultrafiltration process," Chemical Engineering Journal, vol. 132, no. 1-3, pp. 257-265, 2007.

[223] W. Den and C. J. Wang, "Removal of silica from brackish water by electrocoagulation pretreatment to prevent fouling of reverse osmosis membranes," Separation and Purification Technology, vol. 59, no. 3, pp. 318-325, 2008.

[224] S. K. Nataraj, K. M. Hosamani, and T. M. Aminabhavi, "Distillery wastewater treatment by the membrane-based nanofiltration and reverse osmosis processes," Water Research, vol. 40, no. 12, pp. 2349-2356, 2006.

[225] S. K. Nataraj, K. M. Hosamani, and T. M. Aminabhavi, "Nanofiltration and reverse osmosis thin film composite membrane module for the removal of dye and salts from the simulated mixtures," Desalination, vol. 249, no. 1, pp. 12-17, 2009.

[226] S. K. Nataraj, S. Sridhar, I. N. Shaikha, D. S. Reddy, and T. M. Aminabhavi, "Membrane-based microfiltration/electrodialysis hybrid process for the treatment of paper industry wastewater," Separation and Purification Technology, vol. 57, no. 1, pp. 185-192, 2007.

[227] AIChE Report on Separation Technology Workshops, Vision 2020: 2000 Separations Roadmap, American Institute of Chemical Engineers, New York, NY, USA, 2000. 

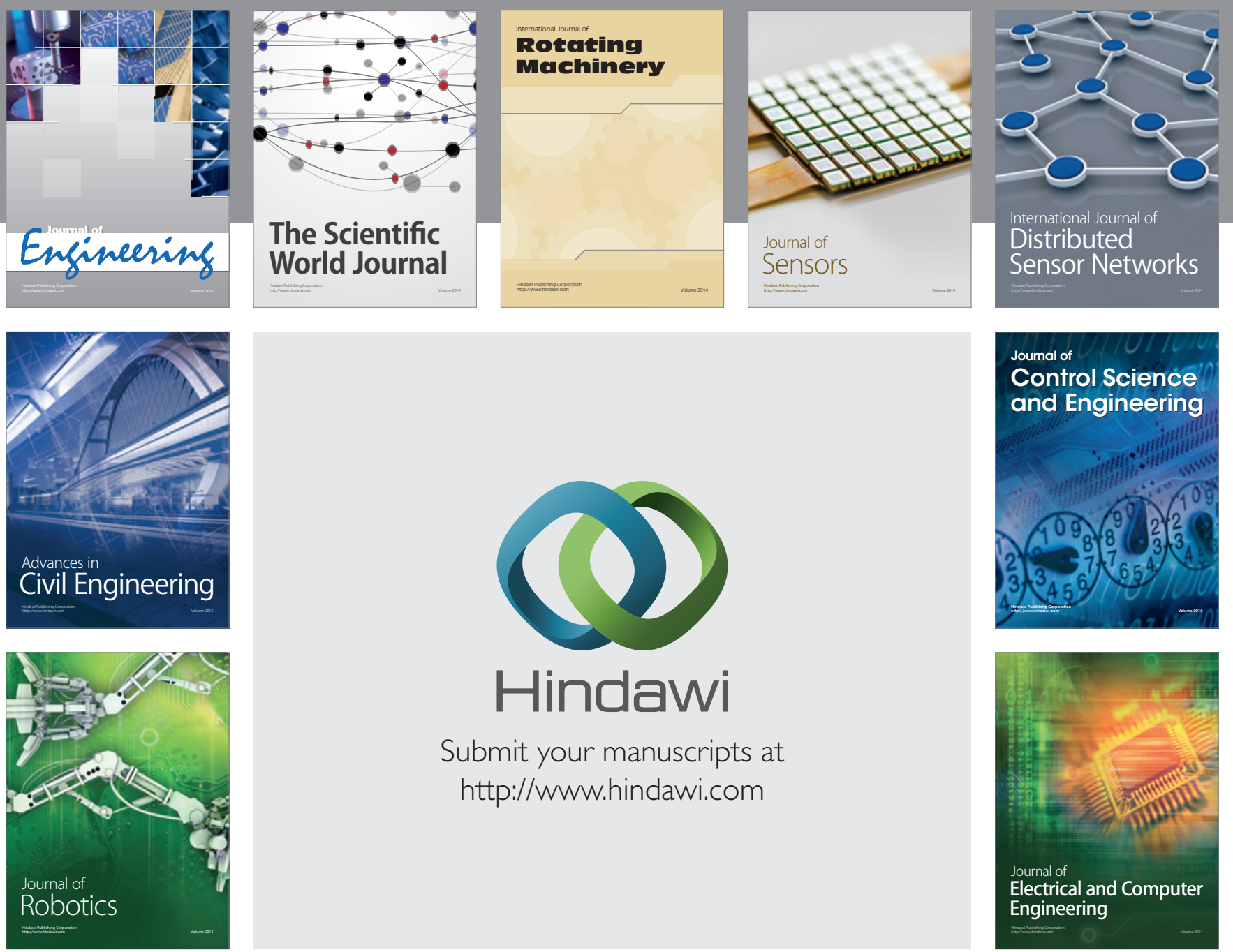

Submit your manuscripts at

http://www.hindawi.com
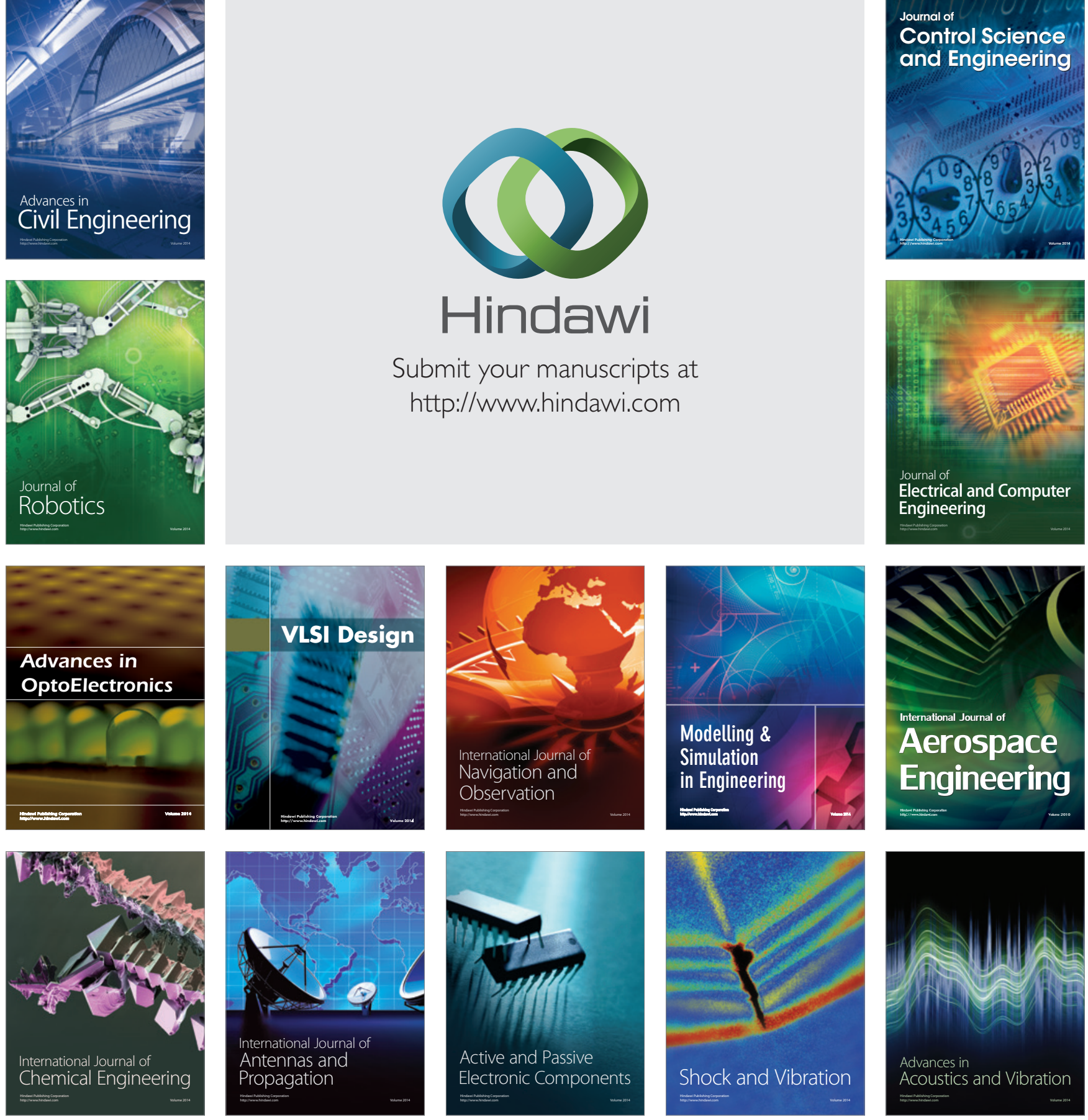